\title{
Comparative genomics reveals 104 candidate structured RNAs from bacteria, archaea, and their metagenomes
}

\author{
Zasha Weinberg ${ }^{1,2^{*}}$, Joy X Wang ${ }^{1}$, Jarrod Bogue ${ }^{2,4}$, Jingying Yang ${ }^{2}$, Keith Corbino ${ }^{1}$, Ryan H Moy ${ }^{2,5}$, \\ Ronald R Breaker ${ }^{1,2,3^{*}}$
}

\begin{abstract}
Background: Structured noncoding RNAs perform many functions that are essential for protein synthesis, RNA processing, and gene regulation. Structured RNAs can be detected by comparative genomics, in which homologous sequences are identified and inspected for mutations that conserve RNA secondary structure.

Results: By applying a comparative genomics-based approach to genome and metagenome sequences from bacteria and archaea, we identified 104 candidate structured RNAs and inferred putative functions for many of these. Twelve candidate metabolite-binding RNAs were identified, three of which were validated, including one reported herein that binds the coenzyme S-adenosylmethionine. Newly identified cis-regulatory RNAs are implicated in photosynthesis or nitrogen regulation in cyanobacteria, purine and one-carbon metabolism, stomach infection by Helicobacter, and many other physiological processes. A candidate riboswitch termed $\operatorname{crcB}$ is represented in both bacteria and archaea. Another RNA motif may control gene expression from 3'-untranslated regions of mRNAs, which is unusual for bacteria. Many noncoding RNAs that likely act in trans are also revealed, and several of the noncoding RNA candidates are found mostly or exclusively in metagenome DNA sequences.

Conclusions: This work greatly expands the variety of highly structured noncoding RNAs known to exist in bacteria and archaea and provides a starting point for biochemical and genetic studies needed to validate their biologic functions. Given the sustained rate of RNA discovery over several similar projects, we expect that far more structured RNAs remain to be discovered from bacterial and archaeal organisms.
\end{abstract}

\section{Background}

Ongoing efforts to identify and characterize various structured noncoding RNAs from bacteria are revealing the remarkable functions that structured RNAs can perform [1-3]. To detect novel RNA classes in bacteria and archaea, a variety of bioinformatics strategies have been used [4-12]. In our recent efforts to identify novel structured RNAs, we applied a scheme based on detecting RNA secondary structures upstream of homologous protein-coding genes $[13,14]$. However, this strategy is best suited to finding cis-regulatory RNAs, not noncoding RNAs. Also, some cis-regulatory RNAs such as c-di-

\footnotetext{
* Correspondence: zasha.weinberg@yale.edu; ronald.breaker@yale.edu
${ }^{1}$ Howard Hughes Medical Institute, Yale University, P.O. Box 208103, New

* Correspondence: zasha.weinberg@yale.edu; ronald.breaker@yale.edu
${ }^{1}$ Howard Hughes Medical Institute, Yale University, P.O. Box 208103, New Haven, CT 06520-8103, USA
}

(c) 2010 Weinberg et al.; licensee BioMed Central, Ltd. This is an open access article distributed under the terms of the Creative Commons Attribution License (http://creativecommons.org/licenses/by/2.0), which permits unrestricted use, distribution, and reproduction in any medium, provided the original work is properly cited.

GMP riboswitches [14,15] or $y d a O$ motif RNAs [5] are not often found upstream of homologous genes [13].

We therefore implemented a search system that is independent of protein-coding genes. In brief, our system clusters intergenic regions (IGRs) [16] by using a BLAST-based method [17] and infers secondary structures by using CMfinder [18]. Then, as before [19,20], the identified structures are used in homology searches to find homologues that allow CMfinder to refine further its structural alignment. The resulting alignments are scored and then analyzed manually to identify the most promising candidates and to infer possible biologic roles.

This method was applied to all available bacterial and archaeal genome sequences, as well as metagenome (that is, environmental) sequences, and identified 104 candidate RNA motifs described in this report. Some additional RNAs will be reported later (unpublished data) 
that bind cyclic di-GMP or tetrahydrofolate, that represent diverse variants of hammerhead self-cleaving ribozymes, or that exhibit exceptional characteristics suggesting a novel or unusual biochemical function [21]. In this report, we provide biochemical evidence that members of one of the 104 RNA motifs bind $S$-adenosylhomocysteine (SAH) and $S$-adenosylmethionine (SAM) in vitro, and presumably regulate the downstream genes coding for SAM synthetase. The rest of this report provides predicted structures of selected motifs and hypotheses regarding their biologic roles. The remaining motifs, as well as additional information on the selected motifs, are presented in Additional File 1. Discussions about individual motifs are largely independent, but are grouped into common putative functional roles. A list of all 104 motifs is provided in Table 1 and Additional File 2. Multiple-sequence alignments of motifs, the organisms in which their representatives appear, and predicted flanking genes are available in printable format in Additional File 3, and alignments are provided in machinereadable format in Additional Files 4 and 5. Consensus diagrams for all motifs are depicted in Additional File 6. Selected motifs (Table 1) were submitted for inclusion in the Rfam Database version 10.1 [22].

\section{Results and discussion}

\section{Identification and analysis of RNA structures}

Promising RNA motifs predicted by our automated bioinformatics procedure were subsequently evaluated manually (see Materials and Methods). As previously reported [14], we identified promising motifs by seeking RNAs that exhibit both regions of conserved nucleotide sequence and evidence of secondary structure. Evidence for the latter characteristic involved the identification of nucleotide variation between representatives of a motif that conserves a given structure. For example, one form of covariation involves mutations to two nucleotides that preserve a Watson-Crick base pair. Assessment of covariation can be complicated, because, for example, spurious evidence of covariation is sometimes a consequence of sequence misalignments. Therefore, final covariation assessments were performed manually.

Cis-regulatory RNAs in bacteria are typically located in 5 ' UTRs. However, transcription start sites for most genes have not been experimentally established. Therefore, when a motif commonly resides upstream of coding regions, we usually assume that it resides in 5' UTRs and is a cis-regulatory RNA. Additional analysis of our system and our scheme for naming motifs is described in Additional File 1.

\section{Riboswitch candidates}

Riboswitches $[1,2,23]$ are RNAs that sense metabolites and regulate gene expression in response to changes in metabolite concentrations. Typically, they form domains within 5' UTRs of mRNAs, and their ligand binding triggers a folding change that modulates expression of the downstream gene. Therefore, good riboswitch candidates are consistently located in potential 5' UTRs. Most known riboswitches require complex secondary and tertiary structures to form tight and highly selective binding pockets for metabolite ligands. Therefore, motifs that comprise the strongest riboswitch candidates have complex secondary structures and stretches of highly conserved nucleotide positions. Motifs were analyzed manually according to these criteria.

We identified a total of 12 RNA motifs that exhibited these characteristics. Here we report the validation of a new SAM/SAH-binding RNA class, and analysis of other riboswitch candidates. Experimental validation of cyclic di-GMP-II and tetrahydrofolate riboswitches will be reported elsewhere. Details describing additional experimental validation efforts and ligands tested with other riboswitch candidates are presented in Additional File 1.

\section{SAM/SAH-binding RNA}

The coenzyme SAM and its reaction by-product SAH are frequently targeted ligands for riboswitches. Three structurally unrelated superfamilies [24] of SAM-binding riboswitches [25] and one SAH-binding riboswitch class [26] have been validated previously. All discriminate against SAM or SAH by orders of magnitude, despite the fact that SAM differs from SAH only by a single methyl group and associated positive charge.

Our current search produced a motif, termed SAM/ $\mathrm{SAH}$ (Figure 1a), that is found exclusively in the order Rhodobacterales of $\alpha$-proteobacteria. The RNA motif is consistently found immediately upstream of metK genes, which encode SAM synthetase. Because known SAMbinding riboswitches are frequently upstream of metK genes [25], the element's gene association suggests that it may function as part of a novel SAM-sensing riboswitch class.

A SAM/SAH RNA from Roseobacter sp. SK209-2-6, called "SK209-52 RNA," was subjected to in-line probing [27] in the presence of various concentrations of SAM or SAH (Figure 1b,c). SK209-52 RNA appears to bind SAH with a dissociation constant $\left(K_{\mathrm{D}}\right)$ of $\sim 4.3 \mu M$ and SAM with a $K_{\mathrm{D}}$ of $\sim 8.6 \mu M$ (Figure $1 \mathrm{~d}$ ). Similar results were obtained with SAM/SAH RNA constructs from other species (data not shown). However, because SAM undergoes spontaneous demethylation, SAM samples contain at least some of the breakdown product SAH. Thus, apparent affinity for SAM could result from binding only of contaminating SAH [26]. However, binding assays based on equilibrium dialysis and molecularrecognition experiments indicate that SAM/SAH RNAs do bind SAM (Additional File 1). 
Table 1 Motifs identified in this work

\begin{tabular}{|c|c|c|c|c|c|}
\hline Motif & RNA? & cis-reg? & Switch? & Taxa & Rfam \\
\hline 6S-flavo & $\mathrm{Y}$ & $\mathrm{N}$ & $\mathrm{N}$ & Bacteroidetes & RF01685 \\
\hline aceE & $?$ & $y$ & $?$ & $\gamma$-Proteobacteria & \\
\hline Acido-1 & $y$ & $n$ & $n$ & Acidobacteria & RF01686 \\
\hline Acido-Lenti-1 & $y$ & $n$ & $n$ & Acidobacteria, Lentisphaerae & RF01687 \\
\hline Actino-pnp & $\mathrm{Y}$ & Y & $\mathrm{N}$ & Actinomycetales & RF01688 \\
\hline AdoCbl-variant & $\mathrm{Y}$ & Y & Y & Marine & RF01689 \\
\hline asd & $\mathrm{Y}$ & $?$ & $?$ & Lactobacillales & RF01732 \\
\hline atoc & $y$ & $y$ & $?$ & $\delta$-Proteobacteria & RF01733 \\
\hline Bacillaceae-1 & $\mathrm{Y}$ & $n$ & $n$ & Bacillaceae & RF01690 \\
\hline Bacillus-plasmid & $y$ & $?$ & $n$ & Bacillus & RF01691 \\
\hline Bacteroid-trp & $y$ & $y$ & $n$ & Bacteroidetes & RF01692 \\
\hline Bacteroidales-1 & $\mathrm{Y}$ & $?$ & $?$ & Bacteroidales & RF01693 \\
\hline Bacteroides-1 & $y$ & $?$ & $n$ & Bacteroides & RF01694 \\
\hline Bacteroides-2 & $?$ & $n$ & $n$ & Bacteroides & \\
\hline Burkholderiales-1 & $?$ & $?$ & $n$ & Burkholderiales & \\
\hline C4 antisense RNA & $\mathrm{Y}$ & $\mathrm{N}$ & $\mathrm{N}$ & Proteobacteria, phages & RF01695 \\
\hline$c 4-a 1 b 1$ & $\mathrm{Y}$ & $\mathrm{N}$ & $\mathrm{N}$ & $\gamma$-Proteobacteria, phages & \\
\hline Chlorobi-1 & $\mathrm{Y}$ & $n$ & $n$ & Chlorobi & RF01696 \\
\hline Chlorobi-RRM & $y$ & $y$ & $n$ & Chlorobi & RF01697 \\
\hline Chloroflexi-1 & $y$ & $?$ & $n$ & Chloroflexus aggregans & RF01698 \\
\hline Clostridiales-1 & $y$ & $n$ & $n$ & Clostridiales, human gut & RF01699 \\
\hline COG2252 & $?$ & $\mathrm{y}$ & $n$ & Pseudomonadales & \\
\hline Collinsella-1 & $y$ & $n$ & $n$ & Actinobacteria, human gut & RF01700 \\
\hline $\operatorname{crc} B$ & $\mathrm{Y}$ & Y & Y & Widespread, bacteria and archaea & RF01734 \\
\hline$\overline{\text { Cyano-1 }}$ & $y$ & $n$ & $n$ & Cyanobacteria, marine & RF01701 \\
\hline Cyano-2 & $\mathrm{Y}$ & $n$ & $n$ & Cyanobacteria, marine & RF01702 \\
\hline Desulfotalea-1 & $?$ & $n$ & $n$ & Proteobacteria & \\
\hline Dictyoglomi-1 & $\mathrm{y}$ & $?$ & $?$ & Dictyoglomi & RF01703 \\
\hline Downstream-peptide & $\mathrm{Y}$ & $y$ & $y$ & Cyanobacteria, marine & RF01704 \\
\hline epsC & $\mathrm{Y}$ & $\mathrm{y}$ & $\mathrm{y}$ & Bacillales & RF01735 \\
\hline fixA & $?$ & $y$ & $n$ & Pseudomonas & \\
\hline Flavo-1 & $\mathrm{y}$ & $n$ & $n$ & Bacteroidetes & RF01705 \\
\hline flg-Rhizobiales & y & y & $\mathrm{n}$ & Rhizobiales & RF01736 \\
\hline$f / p D$ & $\mathrm{y}$ & $?$ & $n$ & Euryarchaeota & RF01737 \\
\hline$g a b T$ & $Y$ & $y$ & $?$ & Pseudomonas & RF01738 \\
\hline Gamma-cis-1 & $?$ & $y$ & $n$ & $\gamma$-Proteobacteria & \\
\hline$g \ln A$ & $\mathrm{Y}$ & Y & $y$ & Cyanobacteria, marine & RF01739 \\
\hline GUCCY-hairpin & $?$ & $?$ & $n$ & Bacteroidetes, Proteobacteria & \\
\hline Gut-1 & $\mathrm{Y}$ & $n$ & $n$ & Human gut only & RF01706 \\
\hline gyrA & $y$ & $y$ & $n$ & Pseudomonas & RF01740 \\
\hline hopC & $\mathrm{y}$ & Y & $?$ & Helicobacter & RF01741 \\
\hline icd & $?$ & $\mathrm{y}$ & $n$ & Pseudomonas & \\
\hline JUMPstart & $y$ & Y & $?$ & $\gamma$-Proteobacteria & RF01707 \\
\hline L17 downstream element & $y$ & $y$ & $n$ & Lactobacillales, Listeria & RF01708 \\
\hline lactis-plasmid & $y$ & $?$ & $n$ & Lactobacillales & RF01742 \\
\hline Lacto-int & $?$ & $?$ & $\mathrm{n}$ & Lactobacillales, phages & \\
\hline
\end{tabular}


Table 1: Motifs identified in this work (Continued)

\begin{tabular}{|c|c|c|c|c|c|}
\hline Lacto-rpoB & $\mathrm{Y}$ & $\mathrm{y}$ & $n$ & Lactobacillales & RF0170s \\
\hline Lacto-usp & $\mathrm{Y}$ & $?$ & $?$ & Lactobacillales & RF01710 \\
\hline Leu/phe leader & $\mathrm{Y}$ & Y & $\mathrm{N}$ & Lactococcus lactis & RF01743 \\
\hline livk & $y$ & $\mathrm{y}$ & $?$ & Pseudomonadales & RF0174L \\
\hline Lnt & $y$ & $\mathrm{y}$ & $?$ & Chlorobi & RF01711 \\
\hline manA & $\mathrm{Y}$ & Y & $\mathrm{y}$ & Marine, $\gamma$-Proteobacteria, cyanophage & RF01745 \\
\hline Methylobacterium-1 & $\mathrm{Y}$ & $n$ & $\mathrm{n}$ & Methylobacterium, marine & RF01712 \\
\hline Moco-II & $\mathrm{y}$ & Y & $?$ & Proteobacteria & RF01713 \\
\hline mraW & $\mathrm{y}$ & $\mathrm{y}$ & $?$ & Actinomycetales & RF01746 \\
\hline msik & $\mathrm{Y}$ & Y & $?$ & Actinobacteria & RF01747 \\
\hline Nitrosococcus-1 & $?$ & $n$ & $n$ & Nitrosococcus, Clostridia & \\
\hline nuoG & $\mathrm{y}$ & y & $?$ & Enterobacteriales (incl. E. coli K12) & RF01748 \\
\hline Ocean-V & $\mathrm{y}$ & $\mathrm{n}$ & $\mathrm{n}$ & Marine only & RF01712 \\
\hline Ocean-VI & $?$ & $?$ & $?$ & Marine only & \\
\hline pan & $\mathrm{Y}$ & Y & $?$ & Chloroflexi, Firmicutes, $\delta$-Proteobacteria & RF0174S \\
\hline Pedo-repair & $\mathrm{y}$ & $?$ & $n$ & Pedobacter & RF01715 \\
\hline$p f l$ & $\mathrm{Y}$ & Y & Y & Several phyla & RF0175C \\
\hline pheA & $?$ & $\mathrm{y}$ & $n$ & Actinobacteria & \\
\hline PhotoRC-I & $\mathrm{y}$ & $\mathrm{y}$ & $\mathrm{n}$ & Cyanobacteria, marine & RF01716 \\
\hline PhotoRC-II & $\mathrm{Y}$ & y & $\mathrm{n}$ & Marine, cyanophage & RF01717 \\
\hline Polynucleobacter-1 & $\mathrm{y}$ & y & $?$ & Burkholderiales, fresh water/estuary & RF01718 \\
\hline potC & $\mathrm{y}$ & y & $?$ & Marine only & RF01751 \\
\hline psaA & $\mathrm{Y}$ & $\mathrm{y}$ & $?$ & Cyanobacteria & RF01752 \\
\hline$\overline{p s b N H}$ & $y$ & $\mathrm{y}$ & $n$ & Cyanobacteria, marine & RF01753 \\
\hline Pseudomon-1 & $y$ & $n$ & $n$ & Pseudomonadales & RF0171S \\
\hline Pseudomon-2 & $?$ & $\mathrm{n}$ & $n$ & Pseudomonas & \\
\hline Pseudomon-GGDEF & $?$ & $\mathrm{y}$ & $?$ & Pseudomonas & \\
\hline Pseudomon-groES & $y$ & $y$ & $?$ & Pseudomonas & RF01721 \\
\hline Pseudomon-Rho & $y$ & Y & $n$ & Pseudomonas & RF0172C \\
\hline Pyrobac-1 & $\mathrm{y}$ & $\mathrm{n}$ & $\mathrm{n}$ & Pyrobaculum & RF01722 \\
\hline Pyrobac-HINT & $?$ & $\mathrm{y}$ & $n$ & Pyrobaculum & \\
\hline $\mathrm{radC}$ & $\mathrm{Y}$ & $y$ & $?$ & Proteobacteria & RF0175 \\
\hline Rhizobiales-1 & $?$ & $n$ & $\mathrm{~N}$ & Rhizobiales & \\
\hline Rhizobiales-2 & $y$ & $?$ & $n$ & Rhizobiales & RF01723 \\
\hline Rhodopirellula-1 & $?$ & $y$ & $?$ & Proteobacteria, Planctomycetes & \\
\hline$r m f$ & $Y$ & $y$ & $?$ & Pseudomonadales & RF01755 \\
\hline$r n e-I I$ & $\mathrm{Y}$ & y & $\mathrm{N}$ & Pseudomonadales & RF01756 \\
\hline SAM-Chlorobi & $y$ & Y & $?$ & Chlorobi & RF0172 \\
\hline SAM-I-IV-variant & $\mathrm{Y}$ & Y & Y & Several phyla, marine & RF01725 \\
\hline SAM-II long loops & $\mathrm{Y}$ & Y & Y & Bacteroidetes, marine & RF01726 \\
\hline SAM/SAH riboswitch & $Y$ & Y & Y & Rhodobacterales & RF01727 \\
\hline sanguinis-hairpin & $?$ & $\mathrm{n}$ & $n$ & Streptococcus & \\
\hline$s b c D$ & $y$ & $?$ & $n$ & Burkholderiales & RF0175 \\
\hline SCRE & $?$ & y & $n$ & Streptococcus & \\
\hline Soil-1 & $?$ & $n$ & $n$ & Soil only & \\
\hline Solibacter-1 & $?$ & $n$ & $n$ & Solibacter usitatus & \\
\hline STAXI & $y$ & $?$ & $\mathrm{n}$ & Enterobacteriales & RF01728 \\
\hline
\end{tabular}


Table 1: Motifs identified in this work (Continued)

\begin{tabular}{|c|c|c|c|c|c|}
\hline SUCA-II & $\mathrm{y}$ & $\mathrm{y}$ & $?$ & Pseudomonadales & RF01758 \\
\hline$\underline{\text { sucC }}$ & $\mathrm{Y}$ & Y & $?$ & $\gamma$-Proteobacteria & RF01759 \\
\hline Termite-flg & $\mathrm{Y}$ & $\mathrm{y}$ & $n$ & Termite hind gut only & RF01729 \\
\hline Termite-leu & $\mathrm{y}$ & $?$ & $?$ & Termite hind gut only & RF01730 \\
\hline traj-II & $\mathrm{Y}$ & Y & $n$ & Proteobacteria, Enterococcus faecium & RF01760 \\
\hline Transposase-resistance & $?$ & y & $n$ & Several phyla & \\
\hline TwoAYGGAY & $\mathrm{y}$ & $n$ & $n$ & Human gut, $\gamma$-Proteobacteria, Clostridiales & \\
\hline wcaG & $\mathrm{Y}$ & y & $\mathrm{y}$ & Marine, cyanophage & RF01761 \\
\hline Whalefall-1 & $\mathrm{Y}$ & $\mathrm{n}$ & $n$ & Whalefall only & RF01762 \\
\hline yjdF & $\mathrm{Y}$ & Y & Y & Firmicutes & RF01764 \\
\hline$y k k C-1 \| I$ & $y$ & Y & y & Actinobacteria, $\delta$-Proteobacteria & RF01763 \\
\hline
\end{tabular}

Columns are as follows. "RNA?" : is this motif likely to represent a biological RNA? "Y" = certainly, "y" = probably, "?" = ambiguous, "n" = probably not, "N" = no. "cis-reg" : is the motif cis-regulatory? "switch?" : is the motif a riboswitch? Additional annotation and justification is in Additional File 2. "Taxa" : common taxon/ taxa carrying this motif. Many motifs are discussed only in Additional file 1. "Rfam" : accession numbers of motifs that were submitted to the Rfam database for version 10.1. Note: consensus diagrams of some motifs were presented as supplementary data of a previous report [21] under simplified names: Acido-1 (previously ac-1), Dictyoglomi-1 (dct-1), Gut-1 (gt-1), manA (manA), Termite-flg (tf-1) and Whalefall-1 (wf-1).

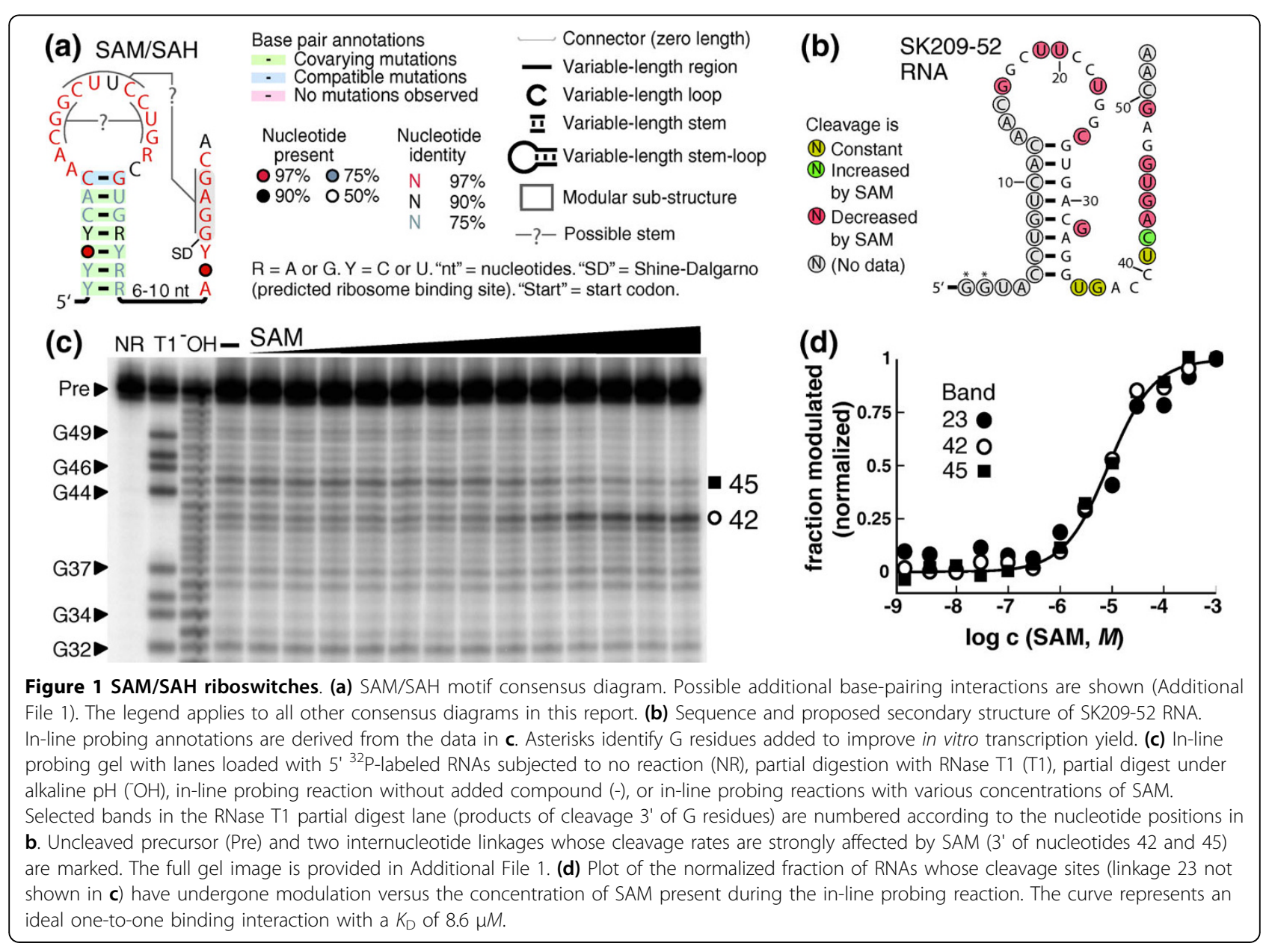


It is interesting to note that SAM/SAH aptamers, which are the smallest of the SAM and SAH aptamer classes, presumably cannot discriminate strongly against SAH. This lack of discrimination may mean that genes associated with this RNA are purposefully regulated by either SAM or SAH. However, SAM is more abundant in cells than is SAH [28]. This fact, coupled with the frequent association of the RNA motif with metK gene contexts of SAM/SAH RNAs, suggests that their biologic role is to function as part of a SAM-responsive riboswitch.

\section{crcB motif}

The $\operatorname{crc} B$ motif (Figure 2) is detected in a wide variety of phyla in bacteria and archaea. Thus, $\operatorname{crcB}$ RNAs join only one known riboswitch class (TPP) [29], and few other classes of RNAs, that are present in more than one domain of life. The $\operatorname{crcB}$ motif consistently resides in the potential $5^{\prime}$ UTRs of genes, including those involved in DNA repair (mutS), $\mathrm{K}^{+}$, or $\mathrm{Cl}^{-}$transport, or genes encoding formate hydrogen lyase. In many cases, predicted transcription terminators overlap the

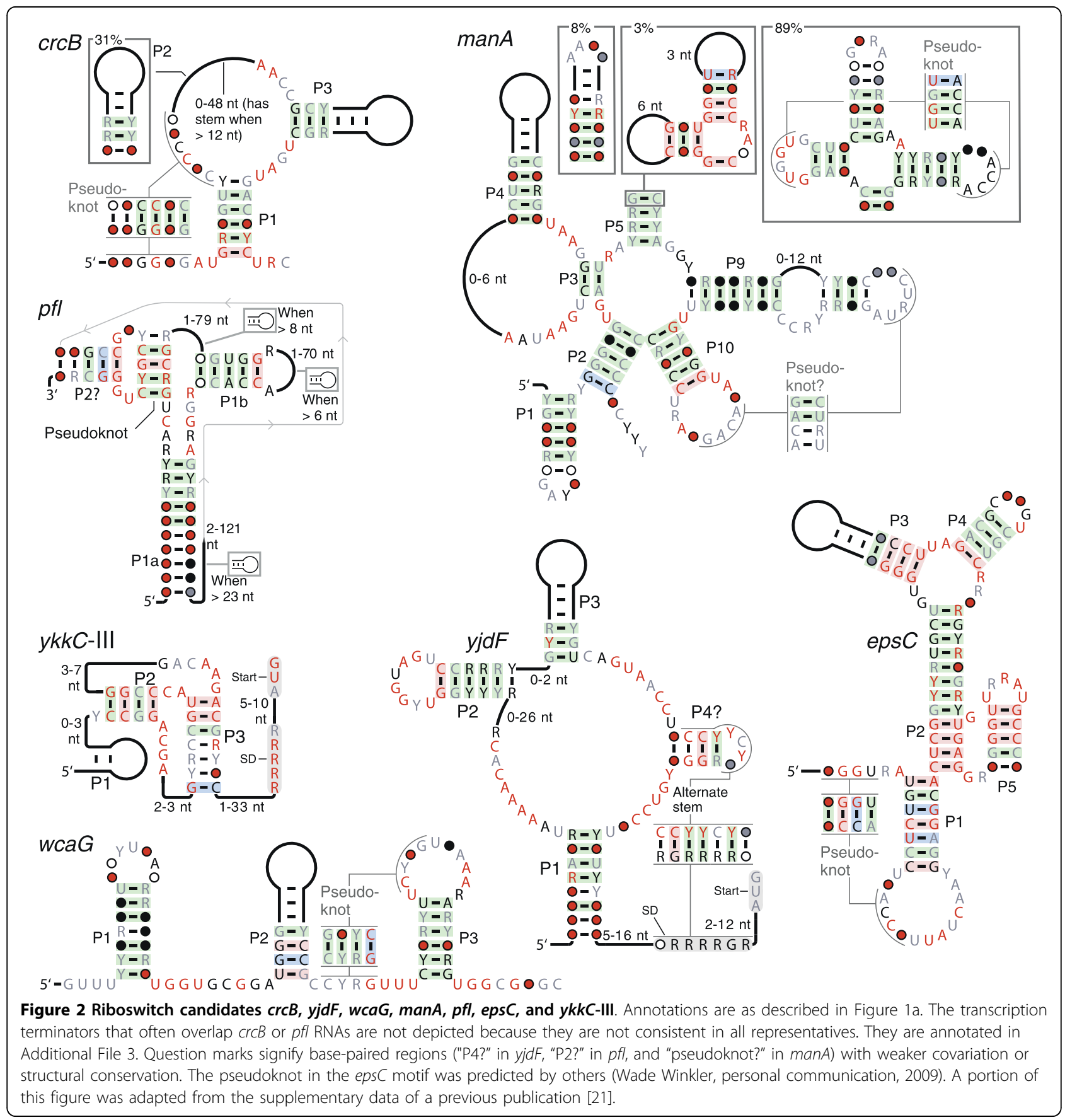


conserved $\operatorname{crcB}$ motif. Therefore, if ligand binding of the putative riboswitch stabilizes the conserved structure predicted for these RNAs, higher ligand concentrations are expected to inhibit terminator stem formation and increase gene expression.

The $\operatorname{crcB}$ motif might regulate genes in response to stress conditions that can damage DNA and be mitigated by increased expression of other genes controlled by the RNAs (Additional File 1). If $\operatorname{crcB}$ RNAs are riboswitches, they presumably sense a metabolite present in organisms that is indicative of a common cellular condition in two domains of life.

\section{pfl motif}

The $p f l$ motif (Figure 2) is found in four bacterial phyla. As with $\operatorname{crcB}$ RNAs, predicted transcription terminators overlap the 3' region of many $p f l$ RNAs; thus, gene expression is likely increased in response to higher ligand concentrations. The genes most commonly associated with $p f l$ RNAs are related to purine biosynthesis, or to synthesis of formyltetrahydrofolate (formyl-THF), which is used for purine biosynthesis. These genes include purH, fhs, pfl, glyA, and folD. PurH formylates AICAR by using formyl-THF as the donor. Formyl-THF can be synthesized by the product of $f h s$ by using formate and THF as substrates. Formate, in turn, is produced in the reaction catalyzed by Pfl. The upregulation of Pfl to create formate for the synthesis of purines was observed previously [30]. Formyl-THF can also be produced from THF and serine by the combined action of GlyA and FolD. Thus, the five genes most commonly predicted to be regulated by $p f l$ RNAs have a role in the synthesis of purines or formyl-THF. Most other genes apparently regulated by pfl RNAs (Additional File 3) encode enzymes that perform other steps in purine synthesis, or convert between THF or its 1-carbon adducts at least as a side effect (for example, metH) (Additional File 1).

\section{yjdF motif}

The $y j d F$ motif (Figure 2) is found in many Firmicutes, including Bacillus subtilis. In most cases, it resides in potential 5' UTRs of homologues of the $y j d F$ gene (Additional File 7), whose function is unknown. However, in Streptococcus thermophilus, a yjdF RNA motif is associated with an operon whose protein products synthesize nicotinamide adenine dinucleotide $\left(\mathrm{NAD}^{+}\right)$ (Additional File 3). Also, the S. thermophilus yjdF RNA lacks typical $y j d F$ motif consensus features downstream of and including the P4 stem. Thus, if yjdF RNAs are riboswitch aptamers, the $S$. thermophilus RNAs might sense a distinct compound that structurally resembles the ligand bound by other yjdF RNAs. Or perhaps these RNAs have an alternate solution to form a similar binding site, as is observed with some SAM riboswitches [24].

\section{manA and wcaG motifs}

The $m a n A$ and $w c a G$ motifs (Figure 2) are found almost exclusively in marine metagenome sequences, but are each detected in T4-like phages that infect cyanobacteria (Additional File 3). Also, two manA RNAs are found in $\gamma$-proteobacteria. Remarkably, many phages of cyanobacteria have incorporated genes involved in metabolism, including exopolysaccharide production and photosynthesis [31-33], and some of these cyanophages carry $\operatorname{man} A$ or wcaG RNAs. RNA domains corresponding to the manA motif are commonly located in potential 5' UTRs of genes (Additional File 3) involved in mannose or fructose metabolism, nucleotide synthesis, $i b p A$ chaperones, and photosynthetic genes. Distinctively, wcaG RNAs typically appear to regulate genes related to production of exopolysaccharides or genes that are induced by high-light conditions. Perhaps manA and wcaG RNAs are used by phages to modify their hosts' metabolism [33], although they may also be exploited by uninfected bacteria.

\section{epsC motif}

RNA domains corresponding to the epsC motif (Figure 2) are found in potential 5' UTRs of genes related to exopolysaccharide (EPS) synthesis, such as epsC [34], in B. subtilis and related species. Different species use different chemical subunits in their EPS [35], which acts in processes such as biofilm formation, capsule synthesis, and sporulation [35-37]. If epsC RNAs are riboswitches, they might sense an intermediate in EPS synthesis that is common to all bacteria containing epsC RNAs. Signalling molecules also regulate EPS synthesis in some bacteria $[36,38]$, and are therefore also candidate riboswitch ligands.

The epsC motif was discovered independently by another group and named EAR (W. Winkler, personal communication, 2009). This candidate has been shown to exhibit transcription antitermination activity, likely by directly interacting with protein components of the transcription elongation complex (W. Winkler, personal communication, 2009), and therefore, this RNA motif may not also function as a metabolite-binding RNA. Intriguingly, the JUMPstart sequence motif [39] is found in the 5' UTRs of genes related to polysaccharide synthesis and also is associated with modification of transcriptional elongation [40-43]. We detected a conserved stem-loop structure among JUMPstart elements (Additional File 1).

\section{ykkC-III motif}

The previously identified $y k k C$ [5] and mini- $y k k C$ [14] motifs are associated with genes related to those associated with $y k k C$-III, but these RNAs have distinct conserved sequence and structural features. The new-found $y k k C$-III motif (Figure 2) is in potential 5' UTRs of emrE and speB genes. emrE is the most common gene family 
associated with mini-ykkC and the second most common to be associated with $y k k C$, and $s p e B$ is also associated with $y k k C$ RNAs in many cases (Additional File 8). Although a perfectly conserved ACGA sequence in $y k k C$-III is similar to the less rigidly conserved ACGR terminal loops of mini-ykkC RNAs, the structural contexts are different (Additional File 1). All three RNA motifs have characteristics of gene-control elements that regulate similar genes, and perhaps respond to changing concentrations of the same metabolite. However, unlike mini- $y k k C$, whose small and repetitive hairpin architecture is suggestive of protein binding, both $y k k C$ and $y k k C$-III exhibit more complex structural features that are suggestive of direct metabolite binding.

\section{glnA and Downstream-peptide motifs}

The $g \ln A$ and Downstream peptide motifs carry similar sequence and structural features (Figure 3), although the genes they are associated with are very different. Many genes presumably regulated by $g \ln A$ RNAs are clearly involved in nitrogen metabolism, and include nitrogen regulatory protein $\mathrm{P}_{\mathrm{II}}$, glutamine synthetase, glutamate synthase, and ammonium transporters. Another associated gene is PMT1479, which was the most repressed gene when Prochlorococcus marinus was starved for nitrogen [44]. Some $g \ln A$ RNAs occur in tandem, which is an arrangement previously associated with more-digital gene regulation $[45,46]$.

The Downstream-peptide motif is found in potential $5^{\prime}$ UTRs of cyanobacterial ORFs whose products are typically 17 to 100 amino acids long and are predicted not to belong to a known protein family. We observe a pattern of synonymous mutations and insertions or deletions in multiples of three nucleotides (data not shown), supporting the prediction of a short conserved coding sequence. A previously predicted noncoding RNA called "yfr6" [47] is 250 nucleotides in length and contains a short ORF. The 5' UTRs of these ORFs correspond to Downstream-peptide RNAs. Although only two full-

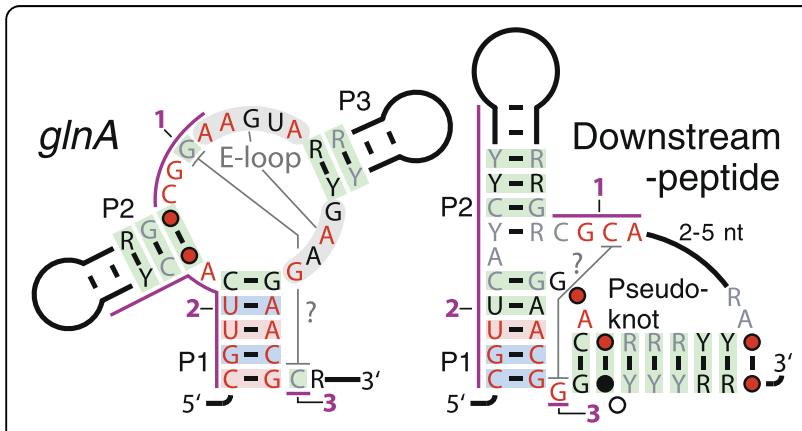

Figure 3 Riboswitch candidates $g \ln A$ and Downstream-peptide Annotations are as described in Figure 1a. Purple lines and numbers indicate conserved sequences or structures common to the two motifs. length yfr6 RNAs were found, 634 Downstream-peptide RNAs were detected, suggesting that only the 5' UTR is conserved. Experiments on yfr6 showed that transcription starts $\sim 20$ nucleotides $5^{\prime}$ to the proposed Downstream-peptide motif [47]. Also, a Downstream-peptide RNA resides in the potential 5' UTR of a gene that appears to be downregulated in response to nitrogen starvation [47]. A conserved amino acid sequence in predicted proteins associated with Downstream-peptide RNAs hints at a possible regulatory mechanism (Additional File 1). The proposed structural resemblance between $g \ln A$ and Downstream-peptide RNAs suggests they may bind to chemically similar ligands, and previously conducted experiments suggest that both elements downregulate genes in response to nitrogen depletion.

\section{Cyanobacterial photosystem regulatory motifs psaA motif}

Representatives of the psaA motif (Figure 4) occur in the potential 5' UTRs of Photosystem-I psaAB operons in certain cyanobacteria. The motif includes three hairpins that often include UNCG tetraloops [48]. Although the regulation of psaAB genes in species with psaA RNAs has not been studied, multiple psa genes in Synechocystis sp. PCC 6803 are regulated in response to light through DNA elements that are presumably transcription factor-binding sites [49]. Photosynthetic organisms upregulate photosystem-I ( $p s a$ ) genes under low-light conditions to maximize energy output, but must reduce their expression under sustained high-light conditions, to avoid damage from free radicals [50]. psaA RNAs could be involved in this regulation, although we have not found this RNA element upstream of $p s a$ genes other than psaAB.

\section{PhotoRC-I, PhotoRC-II, and psbNH motifs}

Two distinct RNA structures (Figure 4) are associated with genes belonging to the photosynthetic reaction center family of proteins that are probably $p s b A$. PhotoRC-I RNAs are present in known cyanobacteria and in marine environmental samples, whereas PhotoRC-II RNAs are detected only in marine samples and a cyanophage. These motifs and $p s b N H$ are further described in Additional File 1.

\section{Other motifs \\ L17 downstream element}

The L17 downstream element (Additional File 6) is located downstream (within the potential 3' UTRs) of genes that encode ribosomal protein L17. In many cases, no annotated genes are located immediately downstream of the element. Although the motif might actually be transcribed in the opposite orientation, the structure as shown is more stable because it carries 


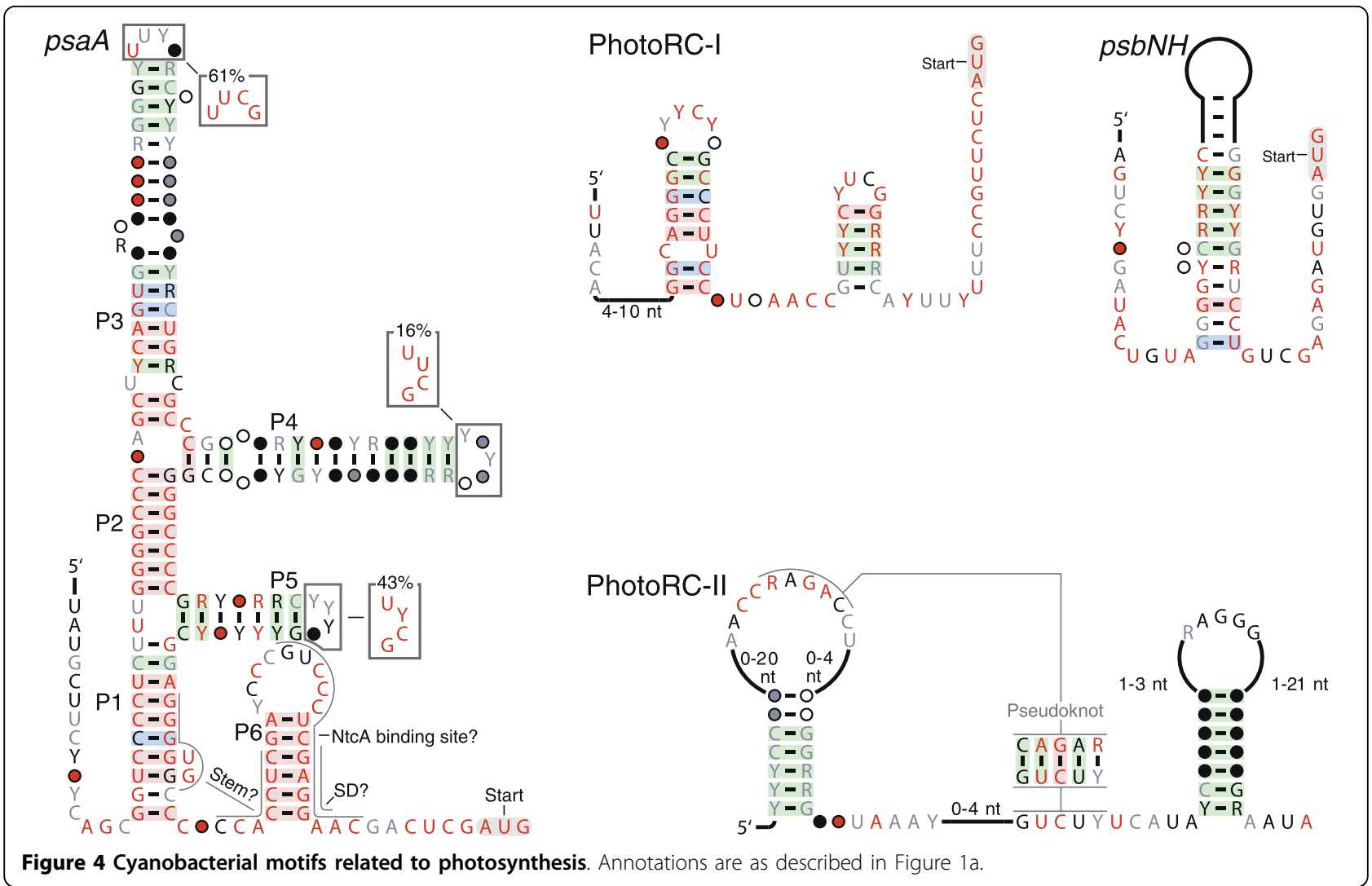

many G-U base pairs and GNRA tetraloops [48]. These structures would be far less stable in the corresponding RNA transcribed from the complementary DNA template. RNA molecules overlapping an L17 downstream element were recently detected by microarrays and designated SR79100 [51]. The expression of ribosomal proteins is frequently regulated by a feedback mechanism in which the protein binds an RNA structure in the 5' UTR of its mRNA, called a ribosomal leader [52]. We did not detect obvious similarity between the L17 downstream element and rRNA, although this situation is typical of ribosomal leaders [53]. Thus, the L17 downstream element could function in the 3' UTR and be part of a feedback-regulation system for L17 production. Regulation of a gene by a structured RNA domain located in the 3' UTR is highly unusual in bacteria. However, precedents include an element in a ribosomal protein operon that regulates both upstream and downstream genes [54], and regulation of upstream genes is observed in a phage [55] and proposed in Listeria [56].

\section{hopC motif}

The hopC motif (Additional File 6) is found in Helicobacter species in the potential 5' UTRs of hopC/alpA gene and co-transcribed hopB/alpB genes. Previous studies established that expression of the hop $C B$ operon is increased in response to low $\mathrm{pH}$ [57]. The experimentally determined 5 ' UTRs of the hop CB operon mRNA in H. pylori 60190 [57] contains a predicted hopC motif RNA. HopCB is needed for optimal binding to human epithelial cells [58] and is presumably involved in infection of the human stomach.

msiK motif

The $m s i K$ motif is always found in the potential 5' UTRs of $m s i K$ genes $[59,60]$, which encode the ATPase subunit for $A B C$-type transporters of at least two complex sugars [61], and probably many more [62]. The motif comprises an 11-nucleotide bulge within a long hairpin. The 3' side of the basal pairing region includes a predicted ribosome binding site, which may be part of the regulatory mechanism. Existing data indicate that $m s i K$ genes are not regulated in response to changing levels of glucose $[59,61]$, so perhaps the RNA participates in a feedback-inhibition loop by binding MsiK proteins (Additional File 1).

\section{pan motif}

The pan motif (Additional File 6) is found in three phyla and is present in the genetically tractable organism B. subtilis. Each pan RNA consists of a stem interrupted by two highly conserved bulged A residues. Most pan RNAs occur in tandem, and their simple structure and dimeric arrangement is suggestive of a dimeric protein-binding motif. The RNAs are located upstream of 
operons containing panB, panC, or aspartate decarboxylase genes, which are involved in synthesizing pantothenate (vitamin $\mathrm{B}_{5}$ ).

\section{rmf motif}

The $r m f$ motif is found in the potential 5' UTRs of $r m f$ genes in Pseudomonas species. These genes encode ribosome-modulation factor, which acts in the stringent response to depletion of nutrients and other stressors [63]. Because Rmf interacts with rRNA, the protein Rmf might bind to the 5 ' UTR of its mRNA. Alternately, because the RNA is relatively far from the $r m f$ start codon, rmf RNAs might be noncoding RNAs that are expressed separate from the adjacent coding region.

\section{SAM-Chlorobi motif}

The SAM-Chlorobi motif is found in the potential $5^{\prime}$ UTRs of operons containing all predicted met $K$ and $a h c Y$ genes within the phylum Chlorobi. As noted earlier, metK encodes SAM synthetase, and in most other organisms, metK homologues are controlled by changing SAM concentrations that are detected by SAM-responsive riboswitches. In contrast, ahc $Y$ encodes $S$-adenosylhomocysteine $(\mathrm{SAH})$ hydrolase, and this gene is known to be controlled by SAH-responsive riboswitches in some organisms [26]. Sequences conforming to a strong promoter sequences $[64,65]$ imply that SAM-Chlorobi RNAs are transcribed (Additional File 1). However, preliminary analysis of several SAM-Chlorobi RNA constructs by using in-line probing did not reveal binding to SAM or SAH (Additional File 1).

\section{STAXI motif}

The Ssbp, Topoisomerase, Antirestriction, XerDC Integrase (STAXI) motif is composed mainly of a pseudoknot structure repeated at least two and usually three times (Figure 5). Tandem STAXI motifs are frequently near to genes that encode proteins that bind or manipulate DNA, including single-stranded DNA-binding proteins (Ssbp), integrases and topoisomerases, or antirestriction proteins. Also, they are occasionally located near c4 antisense RNAs [66] (Additional File 1). Because genes proximal to STAXI representatives encode DNA-manipulation proteins, it is possible that the STAXI motif represents a single-stranded DNA that adopts a local structure when duplex DNA is separated, as occurs during DNA replication, repair, or when bound by some proteins. However, the UUCG tetraloops that frequently occur within the STAXI motif repeats are known to stabilize RNA, whereas the corresponding TTCG are not particularly stabilizing for DNA structures [67]. This suggests that the motif is more likely to serve its function as an RNA structure.

\section{Noncoding RNAs}

Several motifs that are most likely expressed as noncoding RNAs unaffiliated with mRNAs also were identified (Figure 5, Table 1). Gut-1 and whalefall-1 RNAs are found only in environmental sequences, and Bacteroides- 2 is found in only one sequenced organism (Additional File 1). Thus, bacteria from multiple environmental samples express noncoding RNAs that are not represented in any cultivated organisms whose genomes have been sequenced [68,21]. Similarly, Acido1 and Dictyoglomi-1 RNAs are found in phyla in which few genome sequences are available. Further observations regarding all noncoding RNA candidates can be found in Additional File 1.

\section{Expansion of representatives of previously characterized structured RNAs}

Existing homology search methods for RNAs frequently fail to detect representatives of known RNA classes whose sequences have diverged extensively. However, our computational pipeline occasionally reveals examples of such RNAs. Details regarding RNA representatives that expand the collection of 6S RNAs, AdoCbl riboswitches, SAM-II riboswitches, and SAM-I/SAM-IV riboswitches are provided in Additional File 1. The RNAs that expand the collection of the superfamily of SAM-I [69] and SAM-IV [24] riboswitches (Additional File 6) are typically found in metagenome sequences. These variant SAM-I/SAM-IV riboswitches share many of the structural features of both families (Additional File 6), but lack an internal loop in the P2 stem, which is present in SAM-I/SAM-IV riboswitches (Additional File 1).

\section{Conclusions}

Numerous structured RNA candidates have been identified in the genomic and metagenomic DNA sequence data from bacteria and archaea. The predicted RNAs exhibit a great diversity of conserved sequences and structural features, and their genomic locations are indicative of a wide variety of mechanisms of action (for example, cis vs. trans) and putative biologic roles. Our findings suggest that the bacterial and archaeal domains of life will continue to be a rich source of novel structured RNAs.

Although some of the RNAs identified perform the same function as previously validated RNA classes (for example, 6S-Flavo RNA, SAM/SAH riboswitches), the vast majority of the predicted RNA motifs are likely to perform novel functions. Given that many of these RNAs are specific to certain lineages or uncultivated environmental samples, technologies that more rapidly make available DNA sequence information from additional lineages of bacteria and archaea are likely to accelerate the discovery of more classes of structured RNAs. This discovery rate might also be increased by improvements in computational analysis methods. These findings should yield a diverse collection of structured noncoding RNAs that will reveal a more complete understanding of the roles that RNAs perform in microbial cells. 


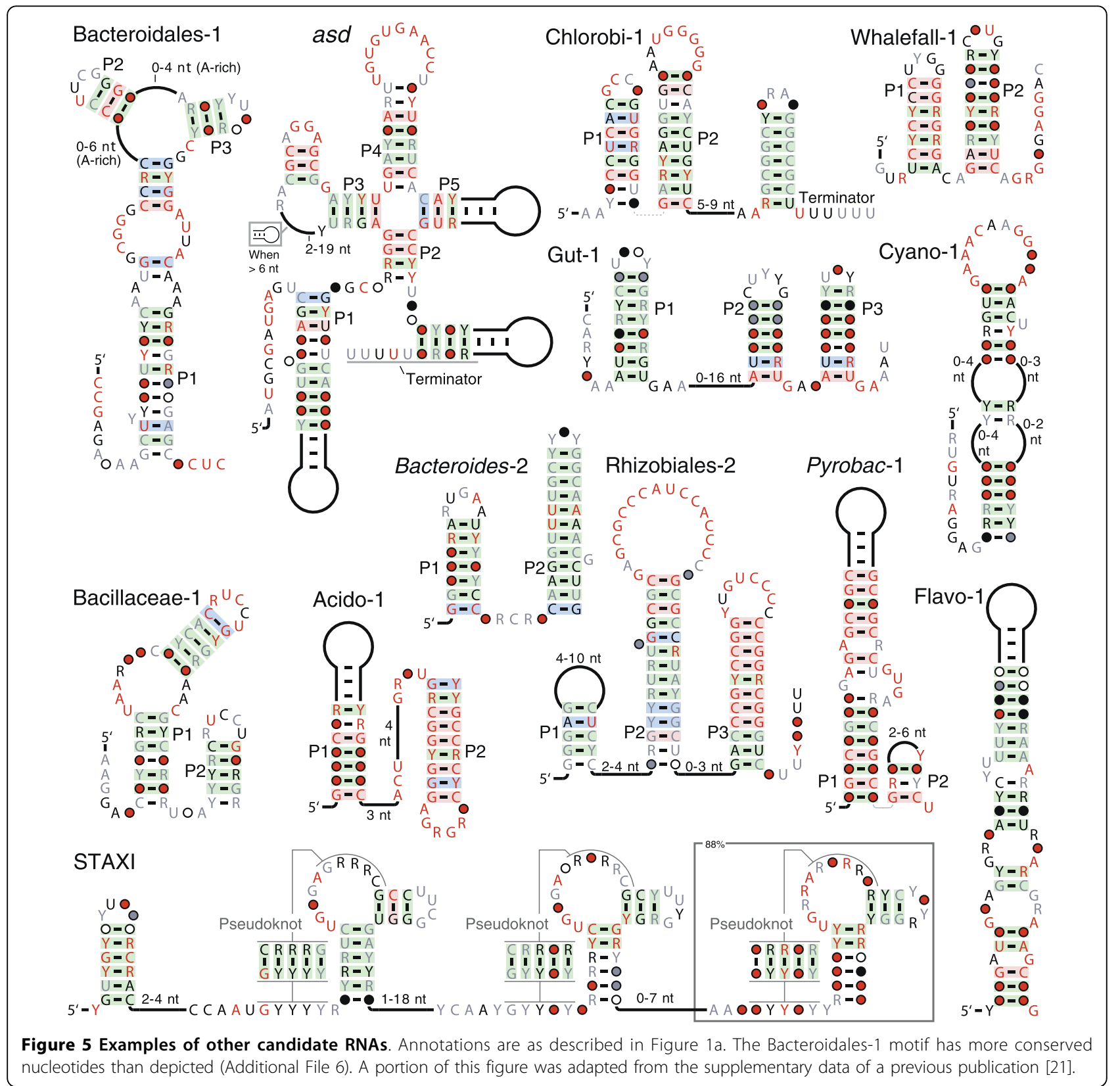

\section{Materials and methods}

DNA sequence sources and gene annotations

The microbial subsets of RefSeq [70] version 25 or 32 (Additional file 9) were searched, along with metagenome sequences from acid mine drainage [71], soil and whale fall [72], human gut [73,74], mouse gut [75], gutless sea worms [76], sludge [77], Global Ocean Survey scaffolds [78,79], other marine sequences [80], and termite hindgut [81]. Locations and identities of proteincoding genes were derived from RefSeq or IMG/M [82] annotations, or from "predicted proteins" [83] in Global Ocean Survey sequences. However, genes in some sequences $[74,80,81]$ were predicted by using MetaGene (dated Oct. 12, 2006) with default parameters [84]. Conserved protein domains were annotated by using the Conserved Domain Database version 2.08 [85].

Annotations for tRNAs and rRNAs were derived from the sources noted earlier, or were predicted by using tRNAscan-SE [86] run in bacterial mode. To detect additional rRNAs, annotated rRNAs whose descriptions read "ribosomal RNA" or "\#S rRNA" (\# represents any number) were used in WU-BLAST queries with command-line flags - hspsepQmax $=4000-E 1 \mathrm{e}-20-\mathrm{W} 8$ [13]. Other RNAs were detected with Rfam [22] and 
WU-BLAST, as described previously [13]. We also used published alignments of riboswitches [87] as queries with RAVENNA global-mode searches [19,20], selecting hits manually based primarily on E-values.

\section{Automated motif identification}

To reduce false positives in sequence comparisons, the pipeline was run separately on related taxa or metagenome sources (Additional File 9). For each run, InterGenic Regions (IGRs) of at least 30 nucleotides were extracted between protein-coding, tRNA and rRNA genes.

To generate clusters, an early version of a recently described algorithm was used [16]. Specifically, IGRs were compared by using nucleotide NCBI BLAST [17] version 2.2.17 and parameters -W 7 -G 2 -E 2 -q -2 -m 8. Selfmatches were ignored. BLAST scores below a parameter $\mathrm{S}$ (see later) were considered insignificant and were ignored. Each BLAST match defines two "nodes," corresponding to the matching sequences. Nodes that overlap by at least five nucleotides are merged, along with their BLAST homologies. A cluster consists of all nodes that have direct or indirect (transitive) BLAST matches. Closely related sequences that span multiple distinct elements in an entire IGR can lead to spurious node merges. Therefore, homologies with BLAST scores $>100$ are ignored.

If a node's length in nucleotides is $\mathrm{L}$, and $\mathrm{L}<500$, then the node is extended on either side by $(500-\mathrm{L}) / 2$ nucleotides, but is constrained to remain within the original IGR. CMfinder can easily tolerate nodes of 500 nucleotides. When $\mathrm{L}>1,000$, nodes are shrunk by ( $\mathrm{L}$ $1,000) / 2$ nucleotides around the center. The $\mathrm{L}>1,000$ case is extremely rare. Only clusters with at least three members were reported.

For each pipeline run, we tried a range of values for the parameter $S=35,40, \ldots, 85$, and determined how many known RNAs were detected with each value. Based on these data, a set of $S$ values was selected manually, and the union of clusters arising from each $\mathrm{S}$ was used as input to CMfinder [18]. CMfinder was used to predict motifs exactly as before [13]. Automated homology searches were then performed as described [13], except that covariance model scores used the null3 model [88]. Motifs were scored by using a previously established method [13], and by using tools comprising Pfold [89] to infer a phylogenetic tree, and then running pscore [90]. We also automatically eliminated motifs that had no covarying base-pair positions, that had an average $\mathrm{G}+\mathrm{C}$ content $<24 \%$, that had representatives whose nucleotide coordinates overlapped the reversecomplements of other representatives on average by $\geq 30 \%$ of their nucleotides, or that had fewer than six positions that were $\geq 97 \%$ conserved (when sequences were weighted with the GSC algorithm). Source code is provided (Additional File 10).

\section{Manual analysis of motifs}

The manual analysis of each candidate RNA motif proceeded essentially as described previously [14]. For motifs that were likely to be cis-regulatory, we routinely searched for articles referencing the locus tags of apparently regulated genes, by using Google Scholar [91]. We also used mutual information analysis [87] to predict additional base-pairing interactions. Motifs less likely to represent structured RNAs were rejected by using previously established criteria [14]. In motif consensus diagrams, covariation and levels of conservation were calculated using earlier protocols [14], but $\leq 10 \%$ noncanonic pairs were tolerated in alignment columns that correspond to conserved base pairs. RNAs were drawn with R2R (Z.W., R.R.B., unpublished software) and Adobe Illustrator.

\section{Assessing the novelty of motifs}

To determine whether the predicted RNA structures were reported previously, we searched the Rfam database [22], and various articles not yet incorporated into Rfam that performed detailed analysis or experiments on newfound candidate RNAs [10,47,92-110]. Although some raw predictions of a previous report [9] overlap some of our RNA motifs (Additional File 11), these raw predictions have never been subjected to detailed evaluation. Additionally, extensive Google searches [111] for genes associated with $\operatorname{crcB}$ RNAs revealed that one of the 358 raw predictions of conserved elements on the RibEx web server [112] overlaps several of the $\operatorname{crcB}$ RNAs we found. This conserved element was called RLE0038 and was not previously subjected to detailed evaluation. We have not determined whether other coinciding predictions are present on this web server because its data are not available in a machine-readable format.

\section{In-line probing experiments}

RNA constructs were prepared by in vitro RNA transcription by using T7 RNA polymerase and the appropriate DNA templates that were created by overlap extension of synthetic DNA oligonucleotides by using SuperScript II reverse transcriptase (Invitrogen), as instructed by the manufacturer. RNA transcripts were purified by using denaturing (8 $M$ urea) polyacrylamide gel electrophoresis (PAGE). RNAs were eluted from the gel, dephosphorylated by using alkaline phosphatase, and $5^{\prime}$ radiolabeled with $\left[\gamma_{-}{ }^{32} \mathrm{P}\right]$ by using methods reported previously [26]. $5^{\prime}$ ${ }^{32} \mathrm{P}$-labeled fragments resulting from in-line probing reactions were subjected to denaturing PAGE, and were imaged and analyzed as previously described [26].

\section{Equilibrium dialysis experiments}

Equilibrium dialysis experiments were conducted in a Dispo-Equilibrium Biodialyzer (The Nest Group, Inc., Southboro, MA, USA), which comprises two chambers 
(A and B) separated by a 5,000-kDa MW cut-off membrane. Chamber A was loaded with $20 \mu$ l solution of 500 $\mathrm{n} M{ }^{3} \mathrm{H}-\mathrm{SAM}$, and Chamber B was loaded with $20 \mu M$ specified RNA in a buffer containing $50 \mathrm{~m} M$ MOPS (pH 7.2 at $20^{\circ} \mathrm{C}$ ), $20 \mathrm{mM} \mathrm{MgCl}$, and $500 \mathrm{mM} \mathrm{KCl}$. The chambers were equilibrated at $25^{\circ} \mathrm{C}$ for $10 \mathrm{~h}$ before a $3-\mu \mathrm{l}$ aliquot was removed from each chamber. Radioactivity of the aliquots was measured with a liquid scintillation counter. Each experiment was repeated 3 times, and average B/A values and standard deviations were calculated.

Additional file 1: Supplementary results and discussion. Additional analysis of motifs, including those not discussed in the manuscript, and in-line probing experiments on riboswitch candidates.

Additional file 2: Summary and evaluation of all motifs. Table 1, with summary of supporting evidence, and numbers of representatives of each motif.

Additional file 3: Taxa of motif representatives, genes flanking representatives and annotated multiple-sequence alignments. For each motif, this file shows the taxa of each motif representative, depicts genes flanking these representatives and describes conserved domains that the genes encode. Also, a multiple-sequence alignment is provided for each motif, and includes secondary structure and other annotations.

Additional file 4: Raw text alignment files, including annotation. Raw alignments of RNAs, including annotations (for example, predicted transcription terminators, flanking sequences) in "Stockholm" text format. The alignment format and appropriate viewing programs are discussed on Wikipedia [113]. The Stockholm files can be retrieved from the .tar.gz archive file by using programs such as WinZip (Windows), Stufflt Expander (Mac), or tar/gzip (UNIX).

Additional file 5: Raw text alignment files, just the motifs. Raw alignments of RNA motifs with minimal annotation and no flanking sequences, in "Stockholm" text format. The Stockholm files can be retrieved from the tar.gz archive file by using programs such as WinZip (Windows), Stufflt Expander (Mac), or tar/gzip (UNIX).

Additional file 6: Consensus diagrams of all motifs. Consensus diagrams depicting all motifs in high resolution.

Additional file 7: Alignment of YjdF proteins. Multiple-sequence alignment of proteins predicted to be homologous to YjdF of Bacillus subtilis.

Additional file 8: Genes associated with $y k k C$, mini-ykkC and $y k k C$-III RNAs. The frequencies with which various gene families are associated with $y k k C$, mini-ykkC or $y k k C-111$ RNAs are listed.

Additional file 9: Partitioning of genomes and metagenomes Describes how genomes and metagenomes were divided into pipeline runs.

Additional file 10: Source code implemented as part of this project. Source code files and a README.pdf file are provided to assist in detailed understanding of the methods. The files can be retrieved from the .tar.gz archive file, as described for Additional file 4.

Additional file 11: Overlap with previous raw predictions. Overlaps of our RNA motifs with raw predictions of a prior study [9]. Tab-delimited text file.

\section{Acknowledgements}

We thank Nick Carriero and Rob Bjornson for assisting our use of the Yale Life Sciences High Performance Computing Center (NIH grant RR19895-02), Paul Gardner for sharing a list of recently published RNA discovery articless, and Adam Roth, Narisiman Sudarsan, Michelle Meyer, Jonathan Perreault, Jeff Barrick, Zizhen Yao, Elizabeth Tseng, Larry Ruzzo, and Breaker lab members for helpful comments. R.R.B. is a Howard Hughes Medical Institute Investigator.

\section{Author details}

${ }^{1}$ Howard Hughes Medical Institute, Yale University, P.O. Box 208103, New Haven, CT 06520-8103, USA. ${ }^{2}$ Department of Molecular, Cellular and Developmental Biology, Yale University, P.O. Box 208103, New Haven, CT 06520-8103, USA. ${ }^{3}$ Department of Molecular Biophysics and Biochemistry, Yale University, P.O. Box 208103, New Haven, CT 06520-8103, USA. ${ }^{4}$ Current address: Department of Biology, University of Rochester, Rochester, NY 14627, USA. ${ }^{5}$ Current address: School of Medicine, University of Pennsylvania, Philadelphia, PA 19104, USA.

\section{Authors' contributions}

ZW and RRB conceived of the study, ZW prepared bioinformatics scripts, and RRB supervised the study. ZW, JY, KC, RM, and JXW analyzed motif predictions to infer conserved RNA structures. JXW, ZW, and JB tested riboswitch candidates by using in-line probing. JXW and JB conducted SAM/ SAH experiments. ZW and RRB wrote the manuscript, with assistance from all authors

Received: 18 November 2009 Revised: 18 January 2010 Accepted: 15 March 2010 Published: 15 March 2010

\section{References}

1. Roth A, Breaker RR: The structural and functional diversity of metabolitebinding riboswitches. Annu Rev Biochem 2009, 78:305-335.

2. Waters LS, Storz G: Regulatory RNAs in bacteria. Cell 2009, 136:615-628.

3. Narberhaus F, Vogel J: Regulatory RNAs in prokaryotes: here, there and everywhere. Mol Microbiol 2009, 74:261-269.

4. Rivas E, Eddy SR: Noncoding RNA gene detection using comparative sequence analysis. BMC Bioinformatics 2001, 2:8.

5. Barrick JE, Corbino KA, Winkler WC, Nahvi A, Mandal M, Collins J, Lee M, Roth A, Sudarsan N, Jona I, Wickiser JK, Breaker RR: New RNA motifs suggest an expanded scope for riboswitches in bacterial genetic control. Proc Natl Acad Sci USA 2004, 101:6421-6426.

6. Corbino KA, Barrick JE, Lim J, Welz R, Tucker BJ, Puskarz I, Mandal M, Rudnick ND, Breaker RR: Evidence for a second class of $S$-adenosylmethionine riboswitches and other regulatory RNA motifs in alpha-proteobacteria. Genome Biol 2005, 6:R70.

7. Meyer IM: A practical guide to the art of RNA gene prediction. Brief Bioinform 2007, 8:396-414.

8. Meyer MM, Ames TD, Smith DP, Weinberg Z, Schwalbach MS, Giovannoni SJ, Breaker RR: Identification of candidate structured RNAs in the marine organism Candidatus 'Pelagibacter ubique'. BMC Genomics 2009, 10:268.

9. Livny J, Teonadi H, Livny M, Waldor MK: High-throughput, kingdom-wide prediction and annotation of bacterial non-coding RNAs. PLOS One 2008, 3:e3197.

10. Marchais A, Naville M, Bohn C, Bouloc P, Gautheret D: Single-pass classification of all noncoding sequences in a bacterial genome using phylogenetic profiles. Genome Res 2009, 19:1084-1092.

11. Klein RJ, Misulovin Z, Eddy SR: Noncoding RNA genes identified in AT-rich hyperthermophiles. Proc Natl Acad Sci USA 2002, 99:7542-7547.

12. Schattner $P$ : Searching for RNA genes using base-composition statistics. Nucleic Acids Res 2002, 30:2076-2082.

13. Yao Z, Barrick J, Weinberg Z, Neph S, Breaker R, Tompa M, Ruzzo WL: A computational pipeline for high-throughput discovery of cis -regulatory noncoding RNA in prokaryotes. PLoS Comput Biol 2007, 3:e126.

14. Weinberg Z, Barrick JE, Yao Z, Roth A, Kim JN, Gore J, Wang JX, Lee ER, Block KF, Sudarsan N, Neph S, Tompa M, Ruzzo WL, Breaker RR: Identification of 22 candidate structured RNAs in bacteria using the CMfinder comparative genomics pipeline. Nucleic Acids Res 2007, 35:4809-4819.

15. Sudarsan N, Lee ER, Weinberg Z, Moy RH, Kim JN, Link KH, Breaker RR: Riboswitches in eubacteria sense the second messenger cyclic di-GMP. Science 2008, 321:411-413.

16. Tseng HH, Weinberg Z, Gore J, Breaker RR, Ruzzo WL: Finding non-coding RNAs through genome-scale clustering. J Bioinform Comput Biol 2009, 7:373-388

17. Altschul SF, Madden TL, Schaffer AA, Zhang J, Zhang Z, Miller W, Lipman DJ: Gapped BLAST and PSI-BLAST: a new generation of protein database search programs. Nucleic Acids Res 1997, 25:3389-3402. 
18. Yao Z, Weinberg Z, Ruzzo WL: CMfinder-a covariance model based RNA motif finding algorithm. Bioinformatics 2006, 22:445-452.

19. Weinberg Z, Ruzzo WL: Sequence-based heuristics for faster annotation of non-coding RNA families. Bioinformatics 2006, 22:35-39.

20. Eddy SR, Durbin R: RNA sequence analysis using covariance models. Nucleic Acids Res 1994, 22:2079-2088.

21. Weinberg Z, Perreault J, Meyer MM, Breaker RR: Exceptional structured noncoding RNAs revealed by bacterial metagenome analysis. Nature 2009, 462:656-659.

22. Gardner PP, Daub J, Tate JG, Nawrocki EP, Kolbe DL, Lindgreen S, Wilkinson AC, Finn RD, Griffiths-Jones S, Eddy SR, Bateman A: Rfam: updates to the RNA families database. Nucleic Acids Res 2009, 37: D136-140.

23. Montange RK, Batey RT: Riboswitches: emerging themes in RNA structure and function. Annu Rev Biophys 2008, 37:117-133.

24. Weinberg Z, Regulski EE, Hammond MC, Barrick JE, Yao Z, Ruzzo WL, Breaker RR: The aptamer core of SAM-IV riboswitches mimics the ligandbinding site of SAM-I riboswitches. RNA 2008, 14:822-828.

25. Wang JX, Breaker RR: Riboswitches that sense S-adenosylmethionine and S-adenosylhomocysteine. Biochem Cell Biol 2008, 86:157-168.

26. Wang JX, Lee ER, Morales DR, Lim J, Breaker RR: Riboswitches that sense $S$-adenosylhomocysteine and activate genes involved in coenzyme recycling. Mol Cell 2008, 29:691-702.

27. Soukup GA, Breaker RR: Relationship between internucleotide linkage geometry and the stability of RNA. RNA 1999, 5:1308-1325.

28. Ueland PM: Pharmacological and biochemical aspects of $S$ -adenosylhomocysteine and S-adenosylhomocysteine hydrolase. Pharmacol Rev 1982, 34:223-253.

29. Sudarsan N, Barrick JE, Breaker RR: Metabolite-binding RNA domains are present in the genes of eukaryotes. RNA 2003, 9:644-647.

30. Derzelle S, Bolotin A, Mistou MY, Rul F: Proteome analysis of Streptococcus thermophilus grown in milk reveals pyruvate formate-lyase as the major upregulated protein. Appl Environ Microbiol 2005, 71:8597-8605.

31. Sullivan MB, Coleman ML, Weigele P, Rohwer F, Chisholm SW: Three Prochlorococcus cyanophage genomes: signature features and ecological interpretations. PLOS Biol 2005, 3:e144.

32. Rohwer $F$, Thurber RV: Viruses manipulate the marine environment. Nature 2009, 459:207-212.

33. Lindell $\mathrm{D}$, Jaffe JD, Coleman ML, Futschik ME, Axmann IM, Rector $T$, Kettler G, Sullivan MB, Steen R, Hess WR, Church GM, Chisholm SW: Genome-wide expression dynamics of a marine virus and host reveal features of co-evolution. Nature 2007, 449:83-86.

34. Lemon KP, Earl AM, Vlamakis HC, Aguilar C, Kolter R: Biofilm development with an emphasis on Bacillus subtilis. Curr Top Microbiol Immunol 2008, 322:1-16.

35. Leoff C, Saile E, Sue D, Wilkins P, Quinn CP, Carlson RW, Kannenberg EL: Cell wall carbohydrate compositions of strains from the Bacillus cereus group of species correlate with phylogenetic relatedness. J Bacteriol 2008, 190:112-121.

36. Nakhamchik A, Wilde C, Rowe-Magnus DA: Cyclic-di-GMP regulates extracellular polysaccharide production, biofilm formation, and rugose colony development by Vibrio vulnificus. Appl Environ Microbiol 2008, 74:4199-4209.

37. Torres-Cabassa A, Gottesman S, Frederick RD, Dolph PJ, Coplin DL: Control of extracellular polysaccharide synthesis in Erwinia stewartii and Escherichia coli K-12: a common regulatory function. J Bacteriol 1987, 169:4525-4531.

38. Liang W, Silva AJ, Benitez JA: The cyclic AMP receptor protein modulates colonial morphology in Vibrio cholerae. Appl Environ Microbiol 2007, 73:7482-7487.

39. Hobbs M, Reeves PR: The JUMPstart sequence: a 39 bp element common to several polysaccharide gene clusters. Mol Microbiol 1994, 12:855-856.

40. Marolda CL, Valvano MA: Promoter region of the Escherichia coli O7specific lipopolysaccharide gene cluster: structural and functional characterization of an upstream untranslated mRNA sequence. J Bacteriol 1998, 180:3070-3079.

41. Nieto JM, Bailey MJ, Hughes C, Koronakis V: Suppression of transcription polarity in the Escherichia coli haemolysin operon by a short upstream element shared by polysaccharide and DNA transfer determinants. Mol Microbiol 1996, 19:705-713.
42. Leeds JA, Welch RA: Enhancing transcription through the Escherichia coli hemolysin operon, hlyCABD: RfaH and upstream JUMPStart DNA sequences function together via a postinitiation mechanism. J Bacteriol 1997, 179:3519-3527.

43. Wang $L$, Jensen $S$, Hallman R, Reeves PR: Expression of the $O$ antigen gene cluster is regulated by RfaH through the JUMPstart sequence. FEMS Microbiol Lett 1998, 165:201-206.

44. Tolonen AC, Aach J, Lindell D, Johnson Zl, Rector T, Steen R, Church GM, Chisholm SW: Global gene expression of Prochlorococcus ecotypes in response to changes in nitrogen availability. Mol Syst Biol 2006, 2:53.

45. Mandal M, Lee M, Barrick JE, Weinberg Z, Emilsson GM, Ruzzo WL, Breaker RR: A glycine-dependent riboswitch that uses cooperative binding to control gene expression. Science 2004, 306:275-279.

46. Welz R, Breaker RR: Ligand binding and gene control characteristics of tandem riboswitches in Bacillus anthracis. RNA 2007, 13:573-582.

47. Axmann IM, Kensche P, Vogel J, Kohl S, Herzel H, Hess WR: Identification of cyanobacterial non-coding RNAs by comparative genome analysis. Genome Biol 2005, 6:R73.

48. Pace NR, Thomas BC, Woese CR: Probing RNA structure, function, and history by comparative analysis. The RNA World Cold Spring Harbor, New York: Cold Spring Harbor Laboratory PressGesteland RF, Cech TR, Atkins JF, 2 1999, 113-141.

49. Muramatsu M, Hihara Y: Coordinated high-light response of genes encoding subunits of Photosystem I is achieved by AT-rich upstream sequences in the cyanobacterium Synechocystis sp. strain PCC 6803. Bacteriol 2007, 189:2750-2758.

50. Muramatsu M, Hihara Y: Characterization of high-light-responsive promoters of the psaAB genes in Synechocystis sp. PCC 6803. Plant Cell Physiol 2006, 47:878-890.

51. Perez N, Trevino J, Liu Z, Ho SC, Babitzke P, Sumby P: A genome-wide analysis of small regulatory RNAs in the human pathogen group $A$ Streptococcus. PLoS One 2009, 4:e7668.

52. Zengel JM, Lindahl L: Diverse mechanisms for regulating ribosomal protein synthesis in Escherichia coli. Prog Nucleic Acid Res Mol Biol 1994, 47:331-370.

53. Batey RT: Structures of regulatory elements in mRNAs. Curr Opin Struct Biol 2006, 16:299-306.

54. Mattheakis L, Vu L, Sor F, Nomura M: Retroregulation of the synthesis of ribosomal proteins L14 and L24 by feedback repressor S8 in Escherichia coli. Proc Natl Acad Sci USA 1989, 86:448-452.

55. Guarneros G, Montanez C, Hernandez T, Court D: Posttranscriptional control of bacteriophage lambda gene expression from a site distal to the gene. Proc Natl Acad Sci USA 1982, 79:238-242.

56. Toledo-Arana A, Dussurget O, Nikitas G, Sesto N, Guet-Revillet $H$, Balestrino D, Loh E, Gripenland J, Tiensuu T, Vaitkevicius K, Barthelemy M, Vergassola M, Nahori MA, Soubigou G, Regnault B, Coppee JY, Lecuit M, Johansson J, Cossart P: The Listeria transcriptional landscape from saprophytism to virulence. Nature 2009, 459:950-956.

57. McGowan CC, Necheva AS, Forsyth MH, Cover TL, Blaser MJ: Promoter analysis of Helicobacter pylori genes with enhanced expression at low pH. Mol Microbiol 2003, 48:1225-1239.

58. Odenbreit $\mathrm{S}$, Faller $\mathrm{G}$, Haas R: Role of the AlpAB proteins and lipopolysaccharide in adhesion of Helicobacter pylori to human gastric tissue. Int J Med Microbiol 2002, 292:247-256.

59. Hurtubise Y, Shareck F, Kluepfel D, Morosoli R: A cellulase/xylanasenegative mutant of Streptomyces lividans 1326 defective in cellobiose and xylobiose uptake is mutated in a gene encoding a protein homologous to ATP-binding proteins. Mol Microbiol 1995, 17:367-377.

60. Parche S, Amon J, Jankovic I, Rezzonico E, Beleut M, Barutcu H, Schendel I, Eddy MP, Burkovski A, Arigoni F, Titgemeyer F: Sugar transport systems of Bifidobacterium longum NCC2705. J Mol Microbiol Biotechnol 2007, 12:9-19.

61. Schlösser A, Kampers T, Schrempf H: The Streptomyces ATP-binding component MsiK assists in cellobiose and maltose transport. J Bacteriol 1997, 179:2092-2095

62. Bertram R, Schlicht M, Mahr K, Nothaft H, Saier MH Jr, Titgemeyer F: In silico and transcriptional analysis of carbohydrate uptake systems of Streptomyces coelicolor A3(2). J Bacteriol 2004, 186:1362-1373.

63. Niven GW, El-Sharoud WM: Ribosome modulation factor. Bacterial Physiology: A Molecular Approach Berlin: Springer-VerlagEl-Sharoud WM 2008, 293-311. 
64. Bayley DP, Rocha ER, Smith CJ: Analysis of cepA and other Bacteroides fragilis genes reveals a unique promoter structure. FEMS Microbiol Lett 2000, 193:149-154

65. Chen S, Bagdasarian M, Kaufman MG, Walker ED: Characterization of strong promoters from an environmental Flavobacterium hibernum strain by using a green fluorescent protein-based reporter system. Appl Environ Microbiol 2007, 73:1089-1100.

66. Citron M, Schuster $\mathrm{H}$ : The c4 repressors of bacteriophages P1 and P7 are antisense RNAs. Cell 1990, 62:591-598

67. Antao VP, Tinoco I Jr: Thermodynamic parameters for loop formation in RNA and DNA hairpin tetraloops. Nucleic Acids Res 1992, 20:819-824.

68. Shi Y, Tyson GW, DeLong EF: Metatranscriptomics reveals unique microbial small RNAs in the ocean's water column. Nature 2009 459:266-269.

69. Winkler WC, Nahvi A, Sudarsan N, Barrick JE, Breaker RR: An mRNA structure that controls gene expression by binding $S$ -adenosylmethionine. Nat Struct Biol 2003, 10:701-707.

70. Pruitt K, Tatusova T, Maglott D: NCBI reference sequence (RefSeq): a curated non-redundant sequence database of genomes, transcripts and proteins. Nucleic Acids Res 2005, 33:D501-D504.

71. Tyson GW, Chapman J, Hugenholtz P, Allen EE, Ram RJ, Richardson PM, Solovyev W, Rubin EM, Rokhsar DS, Banfield JF: Community structure and metabolism through reconstruction of microbial genomes from the environment. Nature 2004, 428:37-43.

72. Tringe SG, von Mering C, Kobayashi A, Salamov AA, Chen K, Chang HW Podar M, Short JM, Mathur EJ, Detter JC, Bork P, Hugenholtz P, Rubin EM: Comparative metagenomics of microbial communities. Science 2005, 308:554-557

73. Gill SR, Pop M, Deboy RT, Eckburg PB, Turnbaugh PJ, Samuel BS, Gordon J, Relman DA, Fraser-Liggett CM, Nelson KE: Metagenomic analysis of the human distal gut microbiome. Science 2006, 312:1355-1359.

74. Kurokawa K, Itoh T, Kuwahara T, Oshima K, Toh H, Toyoda A, Takami H, Morita H, Sharma VK, Srivastava TP, Taylor TD, Noguchi H, Mori H, Ogura Y, Ehrlich DS, Itoh K, Takagi T, Sakaki Y, Hayashi T, Hattori M: Comparative metagenomics revealed commonly enriched gene sets in human gut microbiomes. DNA Res 2007, 14:169-181.

75. Turnbaugh PJ, Ley RE, Mahowald MA, Magrini V, Mardis ER, Gordon J: An obesity-associated gut microbiome with increased capacity for energy harvest. Nature 2006, 444:1027-1031.

76. Woyke $T$, Teeling H, Ivanova NN, Huntemann M, Richter M, Gloeckner FO, Boffelli D, Anderson IJ, Barry KW, Shapiro HJ, Szeto E, Kyrpides NC, Mussmann M, Amann R, Bergin C, Ruehland C, Rubin EM, Dubilier N: Symbiosis insights through metagenomic analysis of a microbial consortium. Nature 2006, 443:950-955

77. Garcia Martin H, Ivanova N, Kunin V, Warnecke F, Barry KW, McHardy AC, Yeates C, He S, Salamov AA, Szeto E, Dalin E, Putnam NH, Shapiro HJ, Pangilinan JL, Rigoutsos I, Kyrpides NC, Blackall LL, McMahon KD, Hugenholtz P: Metagenomic analysis of two enhanced biological phosphorus removal (EBPR) sludge communities. Nat Biotechnol 2006, 24:1263-1269.

78. Rusch DB, Halpern AL, Sutton G, Heidelberg KB, Williamson S, Yooseph S, Wu D, Eisen JA, Hoffman JM, Remington K, Beeson K, Tran B, Smith $\mathrm{H}$, Baden-Tillson H, Stewart C, Thorpe J, Freeman J, Andrews-Pfannkoch C, Venter JE, Li K, Kravitz S, Heidelberg JF, Utterback T, Rogers YH, Falcon LI, Souza V, Bonilla-Rosso G, Eguiarte LE, Karl DM, et al: The Sorcerer II Global Ocean sampling expedition: northwest Atlantic through eastern tropical Pacific. PLOS Biol 2007, 5:e77

79. Venter JC, Remington K, Heidelberg JF, Halpern AL, Rusch D, Eisen JA, Wu D, Paulsen I, Nelson KE, Nelson W, Fouts DE, Levy S, Knap AH, Lomas MW, Nealson K, White O, Peterson J, Hoffman J, Parsons R, BadenTillson $\mathrm{H}$, Pfannkoch C, Rogers YH, Smith HO: Environmental genome shotgun sequencing of the Sargasso Sea. Science 2004, 304:66-74

80. Konstantinidis KT, Braff J, Karl DM, DeLong EF: Comparative metagenomic analysis of a microbial community residing at a depth of 4,000 meters at station ALOHA in the North Pacific subtropical gyre. Appl Environ Microbiol 2009, 75:5345-5355.

81. Warnecke F, Luginbuhl P, Ivanova N, Ghassemian M, Richardson TH, Stege JT, Cayouette M, McHardy AC, Djordjevic G, Aboushadi N, Sorek R, Tringe SG, Podar M, Martin HG, Kunin V, Dalevi D, Madejska J, Kirton E, Platt D, Szeto E, Salamov A, Barry K, Mikhailova N, Kyrpides NC, Matson EG, Ottesen EA, Zhang X, Hernandez M, Murillo C, Acosta LG, et al:
Metagenomic and functional analysis of hindgut microbiota of a woodfeeding higher termite. Nature 2007, 450:560-565.

82. Markowitz VM, Ivanova NN, Szeto E, Palaniappan K, Chu K, Dalevi D, Chen IM, Grechkin Y, Dubchak I, Anderson I, Lykidis A, Mavromatis K, Hugenholtz P, Kyrpides NC: IMG/M: a data management and analysis system for metagenomes. Nucleic Acids Res 2008, 36:D534-D538.

83. Yooseph S, Sutton $G$, Rusch DB, Halpern AL, Williamson SJ, Remington K, Eisen JA, Heidelberg KB, Manning G, Li W, Jaroszewski L, Cieplak P, Miller CS, Li H, Mashiyama ST, Joachimiak MP, van Belle C, Chandonia JM, Soergel DA, Zhai Y, Natarajan K, Lee S, Raphael BJ, Bafna V, Friedman R, Brenner SE, Godzik A, Eisenberg D, Dixon JE, Taylor SS, et al: The Sorcerer II Global Ocean Sampling expedition: expanding the universe of protein families. PLoS Biol 2007, 5:e16.

84. Noguchi H, Park J, Takagi T: MetaGene: prokaryotic gene finding from environmental genome shotgun sequences. Nucleic Acids Res 2006, 34:5623-5630.

85. Marchler-Bauer A, Anderson JB, Cherukuri PF, DeWeese-Scott C, Geer LY, Gwadz M, He S, Hurwitz DI, Jackson JD, Ke Z, Lanczycki CJ, Liebert CA, Liu C, Lu F, Marchler GH, Mullokandov M, Shoemaker BA, Simonyan V, Song JS, Thiessen PA, Yamashita RA, Yin JJ, Zhang D, Bryant SH: CDD: a Conserved Domain Database for protein classification. Nucleic Acids Res 2005, 33:D192-D196.

86. Lowe TM, Eddy SR: tRNAscan-SE: a program for improved detection of transfer RNA genes in genomic sequence. Nucleic Acids Res 1997, 25:955-964.

87. Barrick JE, Breaker RR: The distributions, mechanisms, and structures of metabolite-binding riboswitches. Genome Biol 2007, 8:R239.

88. Nawrocki EP, Kolbe DL, Eddy SR: Infernal 1.0: inference of RNA alignments. Bioinformatics 2009, 25:1335-1337.

89. Knudsen B, Hein J: Pfold: RNA secondary structure prediction using stochastic context-free grammars. Nucleic Acids Res 2003, 31:3423-3428.

90. Yao Z: Genome scale search of noncoding RNAs: bacteria to vertebrates. Seattle, WA: University of Washington; Dissertation 2008.

91. Google Scholar. [http://scholar.google.com].

92. Liu JM, Livny J, Lawrence MS, Kimball MD, Waldor MK, Camilli A: Experimental discovery of sRNAs in Vibrio cholerae by direct cloning, 5S/ tRNA depletion and parallel sequencing. Nucleic Acids Res 2009, 37:e46.

93. Livny J, Brencic A, Lory S, Waldor MK: Identification of 17 Pseudomonas aeruginosa sRNAs and prediction of sRNA-encoding genes in 10 diverse pathogens using the bioinformatic tool sRNAPredict2. Nucleic Acids Res 2006, 34:3484-3493.

94. Sonnleitner E, Sorger-Domenigg T, Madej MJ, Findeiss S, Hackermuller J, Huttenhofer A, Stadler PF, Blasi U, Moll I: Detection of small RNAs in Pseudomonas aeruginosa by RNomics and structure-based bioinformatic tools. Microbiology 2008, 154:3175-3187.

95. Gonzalez N, Heeb S, Valverde C, Kay E, Reimmann C, Junier T, Haas D: Genome-wide search reveals a novel GacA-regulated small RNA in Pseudomonas species. BMC Genomics 2008, 9:167.

96. Steglich C, Futschik ME, Lindell D, Voss B, Chisholm SW, Hess WR: The challenge of regulation in a minimal photoautotroph: non-coding RNAs in Prochlorococcus. PLoS Genet 2008, 4:e1000173.

97. Ulve VM, Sevin EW, Cheron A, Barloy-Hubler F: Identification of chromosomal alpha-proteobacterial small RNAs by comparative genome analysis and detection in Sinorhizobium meliloti strain 1021. BMC Genomics 2007, 8:467.

98. Valverde C, Livny J, Schluter JP, Reinkensmeier J, Becker A, Parisi G: Prediction of Sinorhizobium meliloti sRNA genes and experimental detection in strain 2011. BMC Genomics 2008, 9:416.

99. del Val C, Rivas E, Torres-Quesada O, Toro N, Jimenez-Zurdo Jl: Identification of differentially expressed small non-coding RNAs in the legume endosymbiont Sinorhizobium meliloti by comparative genomics. Mol Microbiol 2007, 66:1080-1091.

100. Saito S, Kakeshita H, Nakamura K: Novel small RNA-encoding genes in the intergenic regions of Bacillus subtilis. Gene 2009, 428:2-8.

101. Padalon-Brauch G, Hershberg R, Elgrably-Weiss M, Baruch K, Rosenshine I, Margalit H, Altuvia S: Small RNAs encoded within genetic islands of Salmonella typhimurium show host-induced expression and role in virulence. Nucleic Acids Res 2008, 36:1913-1927.

102. Pichon C, Felden B: Small RNA genes expressed from Staphylococcus aureus genomic and pathogenicity islands with specific expression among pathogenic strains. Proc Natl Acad Sci USA 2005, 102:14249-14254. 
103. Swiercz JP, Hindra, Bobek J, Haiser HJ, Di Berardo C, Tjaden B, Elliot MA Small non-coding RNAs in Streptomyces coelicolor. Nucleic Acids Res 2008, 36:7240-7251.

104. Rasmussen $\mathrm{S}$, Nielsen $\mathrm{HB}$, Jarmer $\mathrm{H}$ : The transcriptionally active regions in the genome of Bacillus subtilis. Mol Microbiol 2009, 73:1043-1057.

105. Perkins TT, Kingsley RA, Fookes MC, Gardner PP, James KD, Yu L, Assefa SA, He M, Croucher NJ, Pickard DJ, Maskell DJ, Parkhill J, Choudhary J, Thomson NR, Dougan G: A strand-specific RNA-Seq analysis of the transcriptome of the typhoid bacillus Salmonella typhi. PLoS Genet 2009, 5:e1000569.

106. Tezuka $T$, Hara $H$, Ohnishi $Y$, Horinouchi S: Identification and gene disruption of small noncoding RNAs in Streptomyces griseus. J Bacteriol 2009, 191:4896-4904

107. Yoder-Himes DR, Chain PS, Zhu Y, Wurtzel O, Rubin EM, Tiedje JM, Sorek R: Mapping the Burkholderia cenocepacia niche response via highthroughput sequencing. Proc Natl Acad Sci USA 2009, 106:3976-3981.

108. Geissmann T, Chevalier C, Cros MJ, Boisset S, Fechter P, Noirot C, Schrenzel J, Francois P, Vandenesch F, Gaspin C, Romby P: A search for small noncoding RNAs in Staphylococcus aureus reveals a conserved sequence motif for regulation. Nucleic Acids Res 2009, 37:7239-7257.

109. Arnvig KB, Young DB: Identification of small RNAs in Mycobacterium tuberculosis. Mol Microbiol 2009, 73:397-408.

110. Georg J, Voss B, Scholz I, Mitschke J, Wilde A, Hess WR: Evidence for a major role of antisense RNAs in cyanobacterial gene regulation. Mol Syst Biol 2009, 5:305.

111. Google. [http://www.google.com].

112. Abreu-Goodger C, Merino E: RibEx: a web server for locating riboswitches and other conserved bacterial regulatory elements. Nucleic Acids Res 2005, 33:W690-692.

113. Stockholm format. [http://en.wikipedia.org/wiki/Stockholm_format].

114. Fuchs RT, Grundy FJ, Henkin TM: The S(MK) box is a new SAM-binding RNA for translational regulation of SAM synthetase. Nat Struct Mol Biol 2006, 13:226-233.

115. Poiata E, Meyer MM, Ames TD, Breaker RR: A variant riboswitch aptamer class for $S$-adenosylmethionine common in marine bacteria. RNA 2009, 15:2046-2056.

116. Platt MD, Schurr MJ, Sauer K, Vazquez G, Kukavica-lbrulj I, Potvin E, Levesque RC, Fedynak A, Brinkman FS, Schurr J, Hwang SH, Lau GW, Limbach PA, Rowe JJ, Lieberman MA, Barraud N, Webb J, Kjelleberg S, Hunt DF, Hassett DJ: Proteomic, microarray, and signature-tagged mutagenesis analyses of anaerobic Pseudomonas aeruginosa at pH 6.5, likely representing chronic, late-stage cystic fibrosis airway conditions. Bacteriol 2008, 190:2739-2758

117. Sriramulu DD, Nimtz M, Romling U: Proteome analysis reveals adaptation of Pseudomonas aeruginosa to the cystic fibrosis lung environment. Proteomics 2005, 5:3712-3721.

118. Jarrige AC, Mathy N, Portier C: PNPase autocontrols its expression by degrading a double-stranded structure in the pnp mRNA leader. EMBO J 2001, 20:6845-6855.

119. Cardineau GA, Curtiss R: Nucleotide sequence of the asd gene of Streptococcus mutans: identification of the promoter region and evidence for attenuator-like sequences preceding the structural gene. $J$ Biol Chem 1987, 262:3344-3353.

120. Hendriksen WT, Bootsma HJ, Estevao S, Hoogenboezem T, de Jong A, de Groot R, Kuipers OP, Hermans PW: CodY of Streptococcus pneumoniae : link between nutritional gene regulation and colonization. J Bacteriol 2008, 190:590-601

121. Kim K, Meyer RJ: Copy-number of broad host-range plasmid R1162 is regulated by a small RNA. Nucleic Acids Res 1986, 14:8027-8046.

122. Vitreschak AG, Lyubetskaya EV, Shirshin MA, Gelfand MS, Lyubetsky VA: Attenuation regulation of amino acid biosynthetic operons in proteobacteria: comparative genomics analysis. FEMS Microbiol Lett 2004, 234:357-370.

123. Eddy SR: A memory-efficient dynamic programming algorithm for optimal alignment of a sequence to an RNA secondary structure. BMC Bioinformatics 2002, 3:18.

124. Leaphart AB, Thompson DK, Huang K, Alm E, Wan XF, Arkin A, Brown SD, Wu L, Yan T, Liu X, Wickham GS, Zhou J: Transcriptome profiling of Shewanella oneidensis gene expression following exposure to acidic and alkaline pH. J Bacteriol 2006, 188:1633-1642.
125. Storz G, Zheng M: Oxidative stress. Bacterial Stress Responses Washington, DC: ASM PressStorz G, Hengge-Aronis R 2000, 47-59.

126. Lee JC: Structural studies of ribosomal RNA based on cross-analysis of comparative models and three-dimensional crystal structures. Austin, Texas: University of Texas; Dissertation 2003.

127. Frias-Lopez J, Shi Y, Tyson GW, Coleman ML, Schuster SC, Chisholm SW, Delong EF: Microbial community gene expression in ocean surface waters. Proc Natl Acad Sci USA 2008, 105:3805-3810.

128. Forchhammer K: Global carbon/nitrogen control by PII signal transduction in cyanobacteria: from signals to targets. FEMS Microbiol Rev 2004, 28:319-333.

129. Walt $A$, Kahn ML: The fixA and fix $B$ genes are necessary for anaerobic carnitine reduction in Escherichia coli. J Bacteriol 2002, 184:4044-4047.

130. Chou HT, Kwon DH, Hegazy M, Lu CD: Transcriptome analysis of agmatine and putrescine catabolism in Pseudomonas aeruginosa PAO1. $J$ Bacteriol 2008, 190:1966-1975.

131. Espinosa-Urgel M, Ramos JL: Expression of a Pseudomonas putida aminotransferase involved in lysine catabolism is induced in the rhizosphere. Appl Environ Microbiol 2001, 67:5219-5224.

132. Ochsner UA, Wilderman PJ, Vasil Al, Vasil ML: GeneChip expression analysis of the iron starvation response in Pseudomonas aeruginosa: identification of novel pyoverdine biosynthesis genes. Mol Microbiol 2002, 45:1277-1287.

133. Yamanishi $Y$, Mihara $H$, Osaki M, Muramatsu $H$, Esaki N, Sato T, Hizukuri $Y$, Goto S, Kanehisa M: Prediction of missing enzyme genes in a bacterial metabolic network: reconstruction of the lysine-degradation pathway of Pseudomonas aeruginosa. FEBS J 2007, 274:2262-2273.

134. Vencato M, Tian F, Alfano JR, Buell CR, Cartinhour S, DeClerck GA, Guttman DS, Stavrinides J, Joardar V, Lindeberg M, Bronstein PA, Mansfield JW, Myers CR, Collmer A, Schneider DJ: Bioinformatics-enabled identification of the HrpL regulon and type III secretion system effector proteins of Pseudomonas syringae pv. phaseolicola 1448A. Mol Plant Microbe Interact 2006, 19:1193-1206.

135. Bonomo RA, Szabo D: Mechanisms of multidrug resistance in Acinetobacter species and Pseudomonas aeruginosa. Clin Infect Dis 2006, 43(Suppl 2):S49-S56.

136. Duan K, Liu CQ, Supple S, Dunn NW: Involvement of antisense RNA in replication control of the lactococcal plasmid pND324. FEMS Microbiol Lett 1998, 164:419-426.

137. Kok J: Inducible gene expression and environmentally regulated genes in lactic acid bacteria. Antonie Van Leeuwenhoek 1996, 70:129-145.

138. Regulski EE, Moy RH, Weinberg Z, Barrick JE, Yao Z, Ruzzo WL, Breaker RR: A widespread riboswitch candidate that controls bacterial genes involved in molybdenum cofactor and tungsten cofactor metabolism. Mol Microbiol 2008, 68:918-932.

139. Wijayarathna $C D$, Wachi $M$, Nagai K: Isolation of $f t s /$ and murE genes involved in peptidoglycan synthesis from Corynebacterium glutamicum. Appl Microbiol Biotechnol 2001, 55:466-470.

140. Panagiotidis $\mathrm{CH}$, Boos W, Shuman HA: The ATP-binding cassette subunit of the maltose transporter MalK antagonizes MalT, the activator of the Escherichia coli mal regulon. Mol Microbiol 1998, 30:535-546.

141. Ravcheev DA, Gelfand MS, Mironov AA, Rakhmaninova AB: [Purine regulon of gamma-proteobacteria: a detailed description.]. Genetika 2002, 38:1203-1214.

142. Bochner BR, Ames BN: ZTP (5-amino 4-imidazole carboxamide riboside 5'triphosphate): a proposed alarmone for 10-formyl-tetrahydrofolate deficiency. Cell 1982, 29:929-937.

143. Rohlman CE, Matthews RG: Role of purine biosynthetic intermediates in response to folate stress in Escherichia coli. J Bacteriol 1990, 172:7200-7210.

144. Weng M, Nagy PL, Zalkin H: Identification of the Bacillus subtilis pur operon repressor. Proc Natl Acad Sci USA 1995, 92:7455-7459.

145. Su Z, Mao F, Dam P, Wu H, Olman V, Paulsen IT, Palenik B, Xu Y: Computational inference and experimental validation of the nitrogen assimilation regulatory network in cyanobacterium Synechococcus sp. WH 8102. Nucleic Acids Res 2006, 34:1050-1065.

146. Fujita M, Amemura A, Aramaki H: Transcription of the groESL operon in Pseudomonas aeruginosa PAO1. FEMS Microbiol Lett 1998, 163:237-242.

147. Seraphin B: The HIT protein family: a new family of proteins present in prokaryotes, yeast and mammals. DNA Seq 1992, 3:177-179. 
148. Lombardo MJ, Rosenberg SM: radC102 of Escherichia coli is an allele of recG. J Bacteriol 2000, 182:6287-6291.

149. Finn RD, Mistry J, Schuster-Bockler B, Griffiths-Jones S, Hollich V, Lassmann T, Moxon S, Marshall M, Khanna A, Durbin R, Eddy SR, Sonnhammer EL, Bateman A: Pfam: clans, web tools and services. Nucleic Acids Res 2006, 34:D247-D251.

150. Barrett T, Troup DB, Wilhite SE, Ledoux P, Rudnev D, Evangelista C, Kim IF, Soboleva A, Tomashevsky M, Marshall KA, Phillippy KH, Sherman PM, Muertter RN, Edgar R: NCBI GEO: archive for high-throughput functional genomic data. Nucleic Acids Res 2009, 37:D885-D890.

151. Nalca Y, Jansch L, Bredenbruch F, Geffers R, Buer J, Haussler S: Quorumsensing antagonistic activities of azithromycin in Pseudomonas aeruginosa PAO1: a global approach. Antimicrob Agents Chemother 2006, 50:1680-1688.

152. Chugani S, Greenberg EP: The influence of human respiratory epithelia on Pseudomonas aeruginosa gene expression. Microb Pathog 2007, 42:29-35.

153. Diwa A, Bricker AL, Jain C, Belasco JG: An evolutionarily conserved RNA stem-loop functions as a sensor that directs feedback regulation of RNase E gene expression. Genes Dev 2000, 14:1249-1260.

154. Gupta RS: The phylogeny and signature sequences characteristics of Fibrobacteres, Chlorobi, and Bacteroidetes. Crit Rev Microbiol 2004, 30:123-143.

155. Montange RK, Batey RT: Structure of the $S$-adenosylmethionine riboswitch regulatory mRNA element. Nature 2006, 441:1172-1175.

156. Connelly JC, Leach DR: The $s b c C$ and $s b c D$ genes of Escherichia coli encode a nuclease involved in palindrome inviability and genetic recombination. Genes Cells 1996, 1:285-291.

157. Arthur DC, Ghetu AF, Gubbins MJ, Edwards RA, Frost LS, Glover JN: FinO is an RNA chaperone that facilitates sense-antisense RNA interactions. EMBO J 2003, 22:6346-6355.

158. Passalacqua KD, Varadarajan A, Ondov BD, Okou DT, Zwick ME, Bergman NH: Structure and complexity of a bacterial transcriptome. $J$ Bacteriol 2009, 191:3203-3211.

159. Barrick JE, Sudarsan N, Weinberg Z, Ruzzo WL, Breaker RR: 6S RNA is a widespread regulator of eubacterial RNA polymerase that resembles an open promoter. RNA 2005, 11:774-784.

160. Nahvi A, Sudarsan N, Ebert MS, Zou X, Brown KL, Breaker RR: Genetic control by a metabolite binding mRNA. Chem Biol 2002, 9:1043.

161. Nahvi A, Barrick JE, Breaker RR: Coenzyme B12 riboswitches are widespread genetic control elements in prokaryotes. Nucleic Acids Res 2004, 32:143-150.

162. Fox KA, Ramesh A, Stearns JE, Bourgogne A, Reyes-Jara A, Winkler WC, Garsin DA: Multiple posttranscriptional regulatory mechanisms partner to control ethanolamine utilization in Enterococcus faecalis. Proc Natl Acad Sci USA 2009, 106:4435-4440.

163. Regulski EE, Breaker RR: In-line probing analysis of riboswitches. Methods Mol Biol 2008, 419:53-67.

164. Johansen LE, Nygaard P, Lassen C, Agerso Y, Saxild HH: Definition of a second Bacillus subtilis pur regulon comprising the pur and xpt-pbuX operons plus pbuG, nupG (yxjA), and pbuE (ydhL). J Bacteriol 2003, 185:5200-5209.

\section{doi:10.1186/gb-2010-11-3-r31}

Cite this article as: Weinberg et al: Comparative genomics reveals 104 candidate structured RNAs from bacteria, archaea, and their metagenomes. Genome Biology 2010 11:R31.

\section{Submit your next manuscript to BioMed Central and take full advantage of:}

- Convenient online submission

- Thorough peer review

- No space constraints or color figure charges

- Immediate publication on acceptance

- Inclusion in PubMed, CAS, Scopus and Google Scholar

- Research which is freely available for redistribution

Submit your manuscript at www.biomedcentral.com/submit 